\title{
Changes in belowground interactions between white lupin and wheat along nitrogen and phosphorus gradients
}

\section{Simon Boudsocq ( $\nabla$ simon.boudsocq@inrae.fr)}

INRAE Centre Occitanie-Montpellier: Institut National de Recherche pour l'Agriculture l'Alimentation et l'Environnement Centre Occitanie-Montpellier https://orcid.org/0000-0001-9093-834X

\section{Camille Cros}

INRAE Centre Occitanie-Montpellier: Institut National de Recherche pour l'Agriculture l'Alimentation et I'Environnement Centre Occitanie-Montpellier

\section{Philippe Hinsinger}

INRAE Centre Occitanie-Montpellier: Institut National de Recherche pour l'Agriculture l'Alimentation et I'Environnement Centre Occitanie-Montpellier

\section{Hans Lambers}

University of Western Australia

\section{Research Article}

Keywords: Intercropping, nitrogen, phosphorus, stress gradient hypothesis, wheat, white lupin

Posted Date: February 28th, 2022

DOI: https://doi.org/10.21203/rs.3.rs-1382010/v1

License: (9) This work is licensed under a Creative Commons Attribution 4.0 International License. Read Full License 
2 Changes in belowground interactions between white lupin and wheat along nitrogen and

3 phosphorus gradients

4

\section{Author information}

\section{Corresponding Author}

Simon Boudsocq

\section{Acknowledgments}

\section{Abstract}

\section{Background and aims}

UMR Eco\&Sols, Campus SupAgro, Bâtiment 12, 2 place Viala, 34060 Montpellier Cedex 2

simon.boudsocq@inrae.fr

https://orcid.org/0000-0001-9093-834X

We wish to thank Dr Claude Plassard and Dr Isabelle Bertrand for their helpful comments, Jean-Marc Souquet for his help for chemical analyses, and Dr Siobhan Staunton for English editing (UMR Eco\&Sols, INRAE).

The positive effects of cereal-legume intercropping can occur through complementarity and facilitation for the acquisition of soil nitrogen $(N)$ and phosphorus $(P)$. However, the magnitude 
of the benefits depends on the availability of such resources. To improve our understanding and design best-performing systems, we evaluated the performance and underlying mechanisms of a cereal-legume mixture on two crossed gradients of $\mathrm{N}$ and $\mathrm{P}$.

\section{Methods}

In a pot experiment, wheat (Triticum aestivum L.) and white lupin (Lupinus albus L.) were grown separately or together on four levels of $\mathrm{N}$ combined with four levels of $\mathrm{P}$. We compared biomass, $\mathrm{N}$ content, $\mathrm{P}$ content, shoot-to-root biomass ratios and white lupin production of cluster roots and nodules of sole crops with those of intercrops. We used the relative interaction intensity index to determine how the nature of the interaction between the two species changed along the two resource gradients.

\section{Results}

Regardless of $\mathrm{N}$ and $\mathrm{P}$ supply, combined biomass and $\mathrm{N}$ content of intercropped wheat and white lupin were $29 \%$ and $23 \%$ greater, respectively. Intercropping increased P content by $34 \%$, on average, particularly at the lowest $P$ supply. While wheat benefited from intercropping in all treatments, white lupin's performances decreased with increasing $\mathrm{N}$ and P supply, resulting in a shift from mutualism to competition along the two gradients and compensation mechanisms between the two species.

\section{Conclusion}

Nutrient availability negatively influenced the nature and mechanisms of wheat-lupin interaction. However, mutualistic interactions were the less productive, while competition was associated with the more productive situations.

\section{Keywords}

Intercropping; nitrogen; phosphorus; stress gradient hypothesis; wheat; white lupin 


\section{Introduction}

In recent decades, agricultural production has increased dramatically to support the strong global human population growth. This mostly resulted from a significant increase in crop productivity, which has been achieved mainly through an intensive use of chemical inputs such as fertilizers and pesticides or irrigation water, and through the selection of high-yielding crop varieties. This has led to the dominance of poorly diversified agricultural systems (short rotations or monocultures), heavily relying on chemical inputs with various negative consequences on the environment and biodiversity (Steffen et al. 2015; Tilman et al. 2001). It is therefore increasingly recognized that agriculture must evolve towards more sustainable alternatives based on ecological knowledge, such as proposed in the framework of agroecology (Altieri 1989; Duru et al. 2015; Foley et al. 2011; Malézieux 2012).

Among the agroecological solutions proposed for an ecological intensification of agroecosystems, the use of diversity in multiple cropping systems has received considerable attention (Barot et al. 2017; Gaba et al. 2015). This is particularly the case for intercropping, a practice involving two or more species grown together and coexisting for a significant time of their growth cycle (Li et al. 2014; Martin-Guay et al. 2018; Tilman 2020). The benefits of intercropping can arise through different ecological mechanisms such as complementarity between plants and facilitation (Hinsinger et al. 2011). Complementarity occurs when plants differ in their use of a resource, either spatially, temporally or by exploiting different chemical forms (Kahmen et al. 2006; Loreau and Hector 2001). This process has been well documented in intercropping systems, particularly concerning nitrogen $(\mathrm{N})$ acquisition in cereal-legume intercropping systems, in which the cereal exploits soil mineral $\mathrm{N}$ while the legume fixes atmospheric $\mathrm{N}$ symbiotically, thus lowering the negative effect of interspecific competition for N (Bedoussac et al. 2015; Jensen et al. 2020; Li et al. 2009). Facilitation refers to the benefit of one species in the presence of another without any harm; it has also been observed for phosphorus (P) acquisition in cereal-legume intercropping systems (Callaway 1995; Hinsinger et al. 2011; Li et al. 2020, 2014; Tang et al. 2016). Indeed, many legume species have the ability to increase $P$ availability through the acidification of the rhizosphere and the release of carboxylates and phosphatases, which in turn, benefits the cereal (Betencourt et al. 2012; Cu et al. 2005; Li et al. 2016, 2003). 
Knowledge of these ecological mechanisms offers interesting potential for the design of intercropping systems. However, they are known to depend considerably on the availability of resources shared by intercropped species. For example, various studies show that cereallegume intercrops are particularly efficient in low- $\mathrm{N}$-input systems, as reviewed by Bedoussac et al. (2015). Similarly, the benefits of $P$ acquisition through facilitation are greater in conditions where available $P$ is low (e.g., Betencourt et al. 2012). This general observation and the ecological concept of the stress gradient hypothesis lead to the prediction that positive interactions will be more frequent under harsh conditions, and conversely negative interactions more likely under favorable environments (Brooker et al. 2008; Callaway 2007; Yu et al. 2021). Conversely, intercropping can lead to large yield increases, even in highly fertilized systems (Li et al. 2020). In order to intensify the ecological processes of facilitation and complementarity for the acquisition of limiting resources in intercropping systems, a better understanding of how these ecological mechanisms and plant-plant interactions occur in different scenarios of $\mathrm{N}$ and $\mathrm{P}$ input appears fundamental. Cereal-legume intercropping systems are particularly relevant to consider in this respect, as many studies highlighted its benefits for both crops, especially concerning their $\mathrm{N}$ and $\mathrm{P}$ acquisition (Brooker et al. 2015; Bedoussac et al. 2015; Jensen et al. 2020; Tilman 2020; Justes et al. 2021; Li et al. 2021).

In the present study, a cereal and a legume were grown either separately or together on two crossed gradients of $\mathrm{N}$ and $\mathrm{P}$ supply in a pot experiment. Wheat (Triticum aestivum L.) was chosen as the cereal, as it is one of the most widely cultivated and studied crops in the world (FAO 2021), and white lupin (Lupinus albus L.) as the legume. Benefits from intercropping wheat with white lupin have already been demonstrated in previous studies (Cu et al. 2005; Gardner and Boundy 1983; Mariotti et al. 2009). For instance, $\mathrm{Cu}$ and al. (2005) showed an increase of wheat shoot growth and shoot $P$ content of 33 and $45 \%$, respectively, without significantly affecting lupin growth. This result may be due to the ability of white lupin to produce cluster roots that release large quantities of protons and carboxylates such as malate and citrate, especially under low-P conditions, which in turn increase the availability of $\mathrm{P}$ for plants (Gardner et al. 1981; Gardner and Boundy 1983; Hinsinger 2001; Lambers 2022; Lambers et al. 2006). The intermingling of cereal roots with those of white lupin would thus be expected to increase $\mathrm{P}$ availability through facilitation, especially in low-P conditions. 
The objective of this study was to address the following questions: (i) Do wheat and white lupin performances increase in an intercropping system and is the change in performance stable along $\mathrm{N}$ and $\mathrm{P}$ gradients? (ii) How do the cereal and the legume affect each other along the $\mathrm{N}$ and $\mathrm{P}$ gradients? (iii) What are the nature (i.e. positive, neutral or negative) and the underlying mechanisms of their interactions along the $\mathrm{N}$ and $\mathrm{P}$ gradients? (iv) Is there a relationship between the nature of cereal-legume interactions and the mixture performances? The performances of sole crops and intercrops (i.e. biomass, $\mathrm{N}$ uptake and $\mathrm{P}$ uptake) have been compared. Ecological indices of plant mixture and relative performances have been calculated, while belowground traits of lupin (biomass of nodules and cluster roots) have been measured.

\section{Materials and Methods}

\section{Experimental design}

A pot experiment was conducted under glasshouse conditions using a complete factorial design with four levels of $\mathrm{N}$, four levels of $\mathrm{P}$, and three cropping treatments $(\mathrm{T})$ : one with the two species intercropped, and two with each crop grown separately. The levels of $\mathrm{N}$ and $\mathrm{P}$ supplied were based on a preliminary experiment to ensure contrasting responses of plants between different treatments. Plants were grown in a randomized block design with five replicates, so that each combination of factors was represented in each of the five blocks, leading to a total number of 240 pots. Plant density was kept constant through a substitutive design, and chosen to be close to agricultural practices. When grown as sole crops, four individuals were planted in each pot for wheat, while two individuals were planted for white lupin. When intercropped, half the number of individuals of each species were grown.

\section{Plant and soil material}

Lupinus albus L. cv. Feodora and Triticum aestivum L. cv. Lennox were selected for their phenological synchrony. For the sake of simplicity, these species are hereafter referred to simply as lupin and wheat, respectively. Topsoil (0-10 cm depth) of a Luvisol (FAO 2014) with a silty-clay texture was collected from the highest $(\mathrm{P}+)$ and lowest $(\mathrm{P}-) \mathrm{P}$ supply treatments of a long-term P-fertilizer field trial at INRAE (Auzeville, France, $43^{\circ} 31^{\prime} \mathrm{N}, 1^{\circ} 30^{\prime} \mathrm{E}$ ) (Colomb et al. 2007). The composition and properties of these two soils were almost identical apart from the levels of total and available (Olsen-extractable) P (Betencourt et al., 2012). The P-treatment 
had received no $\mathrm{P}$ for 40 years, while $\mathrm{P}+$ was over-fertilized at a rate equivalent to three- to four-fold the actual $\mathrm{P}$ removal by crops. The main properties of $\mathrm{P}$ - soil are: $\mathrm{pH}_{\mathrm{H}_{2} \mathrm{O}}=7.6$, organic $\mathrm{C}=7.4 \mathrm{mg} \mathrm{kg}^{-1} \mathrm{dry}$ soil (heat-loss at $1000^{\circ} \mathrm{C}$ ), total $\mathrm{P}=287 \mathrm{mg} \mathrm{kg}^{-1} \mathrm{dry}$ soil ( $\mathrm{HCl}$ extractable), extractable $\mathrm{P}=6.7 \mathrm{mg} \mathrm{kg}^{-1}$ dry soil (Olsen method), $\mathrm{N}-\mathrm{NO}_{3}{ }^{-}=19 \mathrm{mg} \mathrm{kg}^{-1}$ dry soil and $\mathrm{N}-\mathrm{NH}_{4}{ }^{+}=$ $0.5 \mathrm{mg} \mathrm{kg}^{-1} \mathrm{dry}$ soil ( $\mathrm{KCl}$ extractable). The main properties of the $\mathrm{P}+$ soil are: $\mathrm{pH}_{\mathrm{H}_{2} \mathrm{O}}=7.8$, organic $\mathrm{C}=8.9 \mathrm{mg} \mathrm{kg}^{-1}$ dry soil, total $\mathrm{P}=721 \mathrm{mg} \mathrm{kg}^{-1}$ dry soil, extractable $\mathrm{P}=33.5 \mathrm{mg} \mathrm{kg}^{-1}$ dry soil, $\mathrm{N}$ $\mathrm{NO}_{3}{ }^{-}=20 \mathrm{mg} \mathrm{kg}^{-1}$ dry soil and $\mathrm{N}^{-N_{4}}{ }^{+}=0.6 \mathrm{mg} \mathrm{kg}^{-1}$ dry soil. These two soils were used either alone or in mixtures of $\mathrm{P}$ - and $\mathrm{P}+$ to obtain four different levels of $\mathrm{P}$. In this way it was not necessary to add phosphate salts, which would have resulted in different dynamics, less realistic compared to aged $P$. The $P 1$ treatment was made of $2 / 3$ of $P$ - and $1 / 3$ of $P+$, the $P 2$ treatment was made of $1 / 3$ of $\mathrm{P}$ - and $2 / 3$ of $\mathrm{P}+$, while $\mathrm{P} 0$ and $\mathrm{P} 3$ treatment comprised pure $\mathrm{P}$ and pure $\mathrm{P}+$, respectively. The mixtures of soils and the resulting levels of Olsen-P $\left(\mathrm{mg} \mathrm{P} \mathrm{kg}{ }^{-1}\right)$ dry soil were as follows: P0 (P-) 6.7; P1 (1:2 P-:P+) 13.5; P2 (2:1 P-:P+) 22.5; and P3 (P+) 33.5.

\section{Plant growth conditions}

Pots (20 cm diameter, $15 \mathrm{~cm}$ height) were lined with polyethylene bags to prevent nutrient leaching. The pots were filled with $2 \mathrm{~kg}$ of air-dried soil mixed with $60 \mathrm{~g}$ of perlite to avoid soil compaction due to watering. Soil moisture content was adjusted to $75 \%$ of water holding capacity. $\mathrm{A}^{15} \mathrm{~N}$-enriched urea solution (5\% atom in excess) was added at the beginning of the experiment to determine the proportion of $\mathrm{N}$ derived from symbiotic fixation in lupin. The ${ }^{15} \mathrm{~N}$ enriched urea solution was diluted at four rates resulting in four $\mathrm{N}$ levels: 5, 20, 40 and 100 mg N kg-1 dry soil for N0, N1, N2 and N3 treatments, respectively. No other nutrients were added, because previous studies had shown that only $\mathrm{N}$ and $\mathrm{P}$ were growth limiting. In each sole crop treatment, 12 or six seeds of wheat or lupin were sown per pot, respectively, and plants were thinned a week after emergence to four or two per pot, respectively. In the intercrop treatment, six seeds of wheat were sown with three seeds of lupin, and plantlets were thinned a week after emergence to two and one plants per pot, respectively. Lupin seeds were inoculated with rhizobia (Rhizobium lupini LL13 strain, INRAE, Dijon, France) directly after sowing to ensure good nodulation. Plants were grown in February - April 2015 in a glasshouse with a night temperature of $19^{\circ} \mathrm{C}$ and a day temperature of $24^{\circ} \mathrm{C}$. Light intensity was kept at about $400 \mathrm{~W} \mathrm{~m}^{-2}$ during $16 \mathrm{~h} \mathrm{day}^{-1}$. Pots were weighed daily and watered when necessary to maintain soil water content near $75 \%$ of water holding capacity. Plants were 
harvested 51 days after sowing, at the start of flowering stage, when first pods of lupin had reached $1 \mathrm{~cm}$ and wheat entered the anthesis stage.

\section{Plant measurements}

At harvest, shoots from each pot were cut and roots were gently removed from the soil and washed. In the intercrop treatment, plant parts from each species were collected separately. For lupin, cluster roots and nodules were collected separately from the rest of the root system.

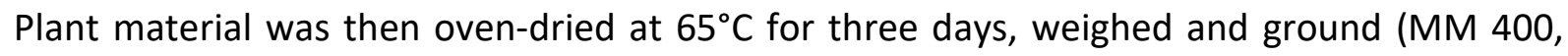
Retsch, Düsseldorf, Germany). Biomass values are expressed per individual plant in each pot (dividing the whole biomass by the number of plant individuals per pot). $\mathrm{N}$-fixation in lupin was calculated with the ${ }^{15} \mathrm{~N}$ isotope dilution method (Unkovich et al. 2008), using the $\% N d f a$ equation (i.e. proportion of $\mathrm{N}$ derived from the atmosphere):

$\% N d f a=\left(\frac{\delta^{15} N_{r e f}-\delta^{15} N_{\text {lupin }}}{\delta^{15} N_{\text {ref }}}\right) \times 100$

$\delta^{15} N_{\text {ref }}$ was obtained with wheat in the sole crop treatment, and for each \% $N d f a$ calculation, we used the $\delta^{15} N_{\text {ref }}$ value obtained in the same plant parts, for identical $\mathrm{N}$ and $\mathrm{P}$ treatments, and in the same replication block as for $\delta^{15} N_{\text {lupin. }}$ \%Ndfa was calculated for shoots (\% $N d f a_{\text {Shoots }}$ ) and roots ( $\% N d f a_{\text {Roots }}$ ), and the total $\% N d f a$ was then obtained with the following equation:

$\% N d f a_{\text {Total }}=\frac{\% N d f a_{\text {Shoots }} \times B_{L_{-} \text {Shoots }}+\% N d f a_{\text {Roots }} \times B_{L_{-} \text {Roots }}}{B_{L_{-} \text {Total }}}$

where $B_{L_{-} \text {Shoots, }} B_{L_{-} \text {Roots }}$ and $B_{L_{-} \text {Total }}$ are the mean individual biomass of shoots, roots and the mean individual total biomass of lupin, respectively. $\delta^{15} \mathrm{~N}$ and $\mathrm{N}$ content were determined with a Stable Isotope Ratio Mass Spectrometer coupled with an Elemental Analyzer (EA/GAIRMS, Carlo Erba, Elementar, Finnigan, Isoprime, Nancy, France). Plant P content was determined using the vanado-molybdate method, as described in Sauvadet et al. (2021).

\section{Interaction indices}

To compare the growth of wheat and lupin grown separately with their growth in mixture (intercrop), we used two interaction indices: the Relative Yield of Mixture (hereafter called RYM (Wilson 1988)) and the Relative Interaction Intensity (hereafter called RII (Armas et al. 2004)). The first quantifies the overall effect of the interaction on both species - at the scale of the mixture. It was calculated as follows: 
where $X_{\text {Lupin_IC }}$ and $X_{\text {Wheat_IC }}$ are, respectively, the mean individual values of any variable measured in lupin and wheat in the intercrop treatment, and $X_{\text {Lupin_sc, }} X_{\text {Wheat_sc }}$ are the mean individual values of the same variable of lupin and wheat in the sole crop, respectively. RYM calculations were made for each $\mathrm{N}$ and $\mathrm{P}$ level combination and with variables measured in the same replication block. In this study, we considered three variables: total biomass $\left(R Y M_{B}\right)$, total $\mathrm{N}$ content $\left(R Y M_{N}\right)$ and total $\mathrm{P}$ content $\left(R Y M_{P}\right)$. The factor of 2 (see equation 3 ) takes account of the greater number of wheat individuals relative to lupin in the intercrops. When $0<R Y M<1$, there was an overall negative effect of intercropping on the studied plant variable, whereas when $1<R Y M$, the overall effect was positive. When $R Y M$ was not significantly different from 1 , intercropping had no effect on the studied variable.

To measure the effect of intercropping at the species level, a second index was calculated for lupin and wheat, respectively:

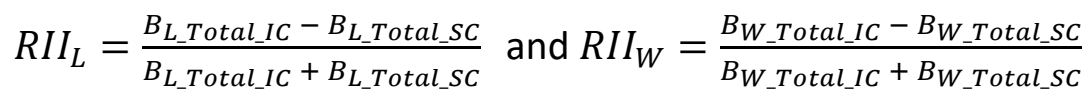

$R I_{L}$ and $R I_{W}$ were calculated for each combination of $\mathrm{N}$ and $\mathrm{P}$ level, using biomass from the same replication block. A negative value of $R / l$ indicates that intercropping had an overall negative effect on species biomass, and a positive value indicates a positive influence. $R / /$ thus provides information on the effects of the interaction at the species level. This allows some determination of the nature of the wheat-lupin interaction.

\section{Statistics}

For each variable, means and standard deviations were calculated from replicates of each treatment ( $n=5$ replicates) and three-way ANOVA was performed to determine the effects of $\mathrm{N}$ supply, P supply and cropping treatments. For plant indices (RYM and RII), comparisons of means among treatments were performed using two-way ANOVA (using $\mathrm{N}$ supply and $\mathrm{P}$ supply as factors), and Student's t-test was carried out to determine the sign of the interaction (positive, negative or neutral) for RII. Following ANOVAs, Tukey HSD post hoc tests and etasquared calculations were carried out. Residuals were verified for normality and homogeneity of variance using Wilk-Shapiro and Levene's tests, respectively. All tests were computed with R 4.4.1 (R Development Core Team, 2021) and statistical significance was set at $P<0.05$. 


\section{Results}

\section{Plant biomass}

229

Total wheat biomass was significantly influenced by each of the three two-way interactions between the three factors, namely "N supply", "P supply" and "cropping" treatments (Table 1, Fig. 1).

There was a significant effect of the interaction between " $N$ " and "P supply" (N:P) on wheat total biomass $\left(P<0.001, \mathrm{Eta}^{2}=0.07\right)$. For a given supply of $\mathrm{N}$, wheat biomass increased with P supply, especially beyond N1 (see Table S1 for Tukey's range post hoc test results). Moreover, with the exception of plants grown at P0, total biomass increased markedly with increasing $\mathrm{N}$ supply.

Table 1. Three-way ANOVA and Eta-squared results for total dry biomass, nitrogen content and phosphorus content in plants with "N supply", "P supply" and "cropping" treatments as factors.

\begin{tabular}{|c|c|c|c|c|c|c|c|c|c|c|c|c|c|}
\hline & & \multicolumn{4}{|c|}{ Total dry biomass } & \multicolumn{4}{|c|}{ Nitrogen content } & \multicolumn{4}{|c|}{ Phosphorus content } \\
\hline & & \multicolumn{2}{|c|}{ Wheat } & \multicolumn{2}{|c|}{ Lupin } & \multicolumn{2}{|c|}{ Wheat } & \multicolumn{2}{|c|}{ Lupin } & \multicolumn{2}{|c|}{ Wheat } & \multicolumn{2}{|c|}{ Lupin } \\
\hline & & $\bar{p}$ & $\mathrm{Eta}^{2}$ & $\bar{p}$ & $\overline{\text { Eta }^{2}}$ & $\bar{p}$ & $\mathrm{Eta}^{2}$ & $\bar{p}$ & $\overline{E \operatorname{ta}^{2}}$ & $\bar{p}$ & $\mathrm{Eta}^{2}$ & $\bar{p}$ & $\mathrm{Eta}^{2}$ \\
\hline Main effects & N supply (N) & $<0.001$ & 0.22 & 0.10 & 0.03 & $<0.001$ & 0.35 & 0.008 & 0.07 & $<0.001$ & 0.20 & $<0.001$ & 0.08 \\
\hline & P supply (P) & $<0.001$ & 0.37 & 0.44 & 0.01 & $<0.001$ & 0.14 & 0.65 & $<0.01$ & $<0.001$ & 0.43 & $<0.001$ & 0.25 \\
\hline & Cropping Treatment $(T)$ & $<0.001$ & 0.22 & 0.20 & $<0.01$ & $<0.001$ & 0.26 & 0.98 & $<0.01$ & $<0.001$ & 0.20 & 0.47 & $<0.01$ \\
\hline Interactions & $N: P$ & $<0.001$ & 0.07 & 0.52 & 0.04 & $<0.001$ & 0.07 & 0.61 & 0.04 & $<0.001$ & 0.07 & 0.014 & 0.07 \\
\hline & $N: T$ & $<0.001$ & 0.01 & 0.02 & 0.05 & $<0.001$ & 0.02 & 0.17 & 0.03 & $<0.001$ & 0.01 & 0.009 & 0.04 \\
\hline & $P: T$ & $<0.001$ & 0.04 & $<0.001$ & 0.18 & $<0.001$ & 0.05 & 0.005 & 0.08 & $<0.001$ & 0.04 & $<0.001$ & 0.11 \\
\hline & $N: P: T$ & 0.31 & $<0.01$ & 0.72 & 0.03 & 0.59 & $<0.01$ & 0.93 & 0.02 & 0.29 & $<0.01$ & 0.42 & 0.03 \\
\hline
\end{tabular}

These results highlight a threshold effect between N1 and N2 levels, beyond which wheat biomass had a stronger response to $\mathrm{P}$ addition. There was another threshold between P0 and $\mathrm{P} 1$ levels beyond which biomass was substantially greater and responded strongly to $\mathrm{N}$ addition. Furthermore, the positive effects of $\mathrm{N}$ and $\mathrm{P}$ addition on wheat biomass were more pronounced in intercropping than in sole cropping treatments $(P<0.001$ for both N:T and P:T interactions). As indicated by the analysis of the main factors, wheat total biomass increased with $\mathrm{N}$ and $\mathrm{P}$ addition, and when intercropped with lupin, explaining $22 \%, 37 \%$ and $22 \%$ of the variation observed in wheat total biomass for "N supply", "P supply" and "cropping" treatments, respectively (see Eta ${ }^{2}$ column in Table 1 ). Consequently, the lowest biomass was achieved at the lowest N and P supply (NOPO) in sole cropping while the greatest biomass was reached at the highest $\mathrm{N}$ and $\mathrm{P}$ supply (N3P3) in intercropping. 


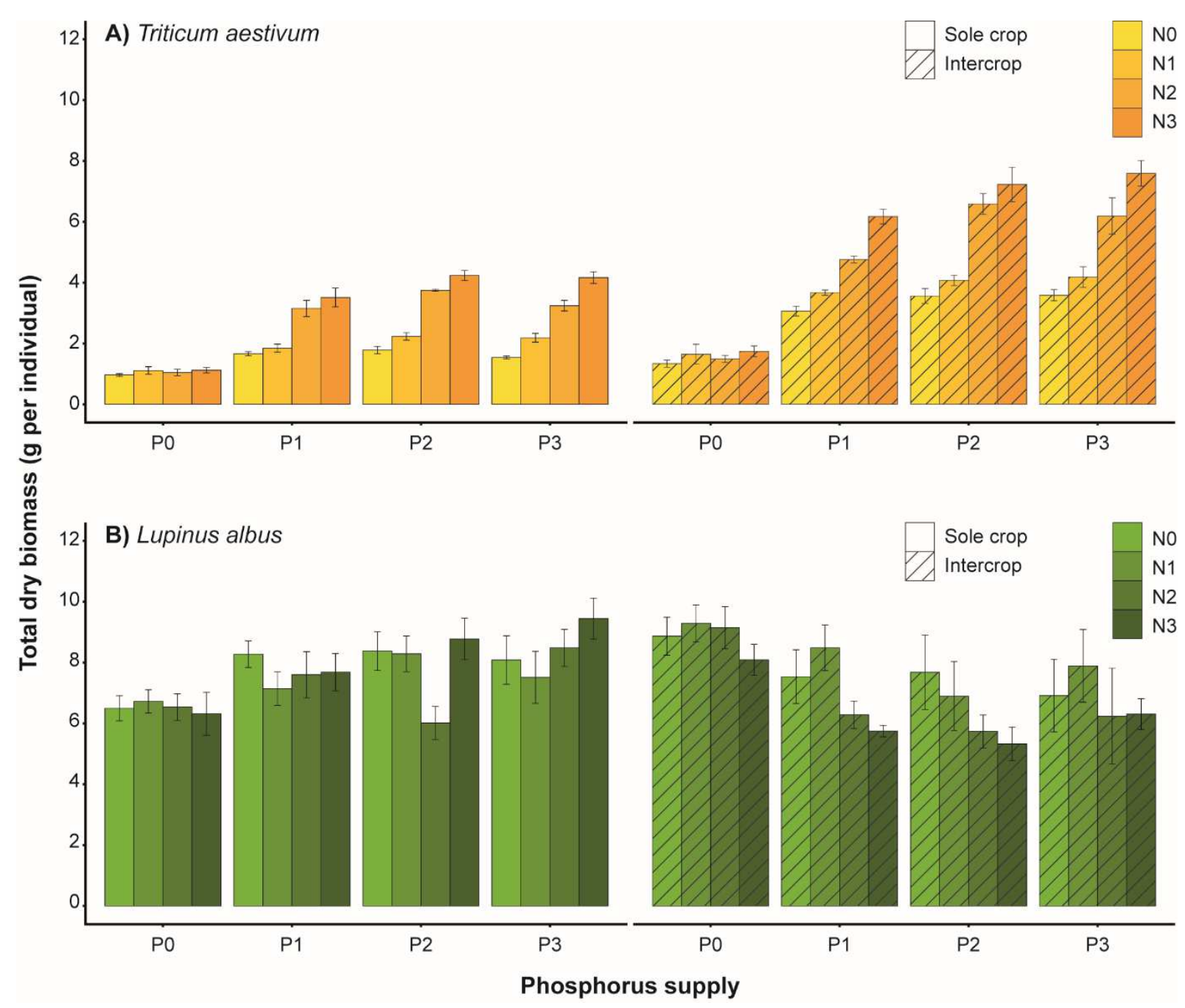

Figure 1. Total biomass of wheat (A) and lupin (B) at the end of the experiment. Vertical bars represent standard error. NO, $N 1, N 2, N 3$ stand for the four levels of $N$, and $P 0, P 1, P 2, P 3$ stand for the four levels of $P$.

For lupin, "P supply" interacted strongly with the "cropping" treatment $\left(P<0.001, \operatorname{Eta}^{2}=0.18\right.$;

Table 1, Fig. 1). When plants were grown as sole crops, there was a significant increase of total biomass between P0 and P3 (Table S1). Conversely, we observed a decrease of total biomass between P0 and other P levels when lupin was intercropped with wheat. In addition, there was a small but significant effect of $\mathrm{N}$ supply on the total biomass of lupin in the intercropping treatment $\left(P<0.05, \mathrm{Eta}^{2}=0.05\right)$. This was only found between lupins grown at $\mathrm{N} 1$, which led to the greatest total biomass, and lupins grown at N3, which led to the lowest total biomass.

\section{Nitrogen content}

262 The total $\mathrm{N}$ content of wheat followed a similar trend to that of biomass. There was a significant effect of each of the two-way interactions between the three factors $(P<0.001$ for $\mathrm{N}: \mathrm{P}, \mathrm{N}: \mathrm{T}$ and P:T; Table 1, Fig. 2). However, the main factors influenced N content differently, 
explaining $35 \%, 14 \%$ and $26 \%$ of the variation observed for "N supply", "P supply" and "cropping" treatments, respectively.

267 The total $\mathrm{N}$ content of lupin was significantly influenced by $\mathrm{N}$ supply $\left(P<0.01, \mathrm{Eta}^{2}=0.07\right)$ and by the interaction between $\mathrm{P}$ supply and cropping treatment $\left(P<0.01, \mathrm{Eta}^{2}=0.08\right.$; Table 1 and Fig. 2). The $\mathrm{N}$ content was significantly greater in lupin grown at the lowest $\mathrm{N}$ level (NO) compared with the highest (N3) level (Table S1). Moreover, at P0, greater N contents were observed in lupin grown with wheat in comparison with lupin grown as sole crop (Table S1, Fig. 2).

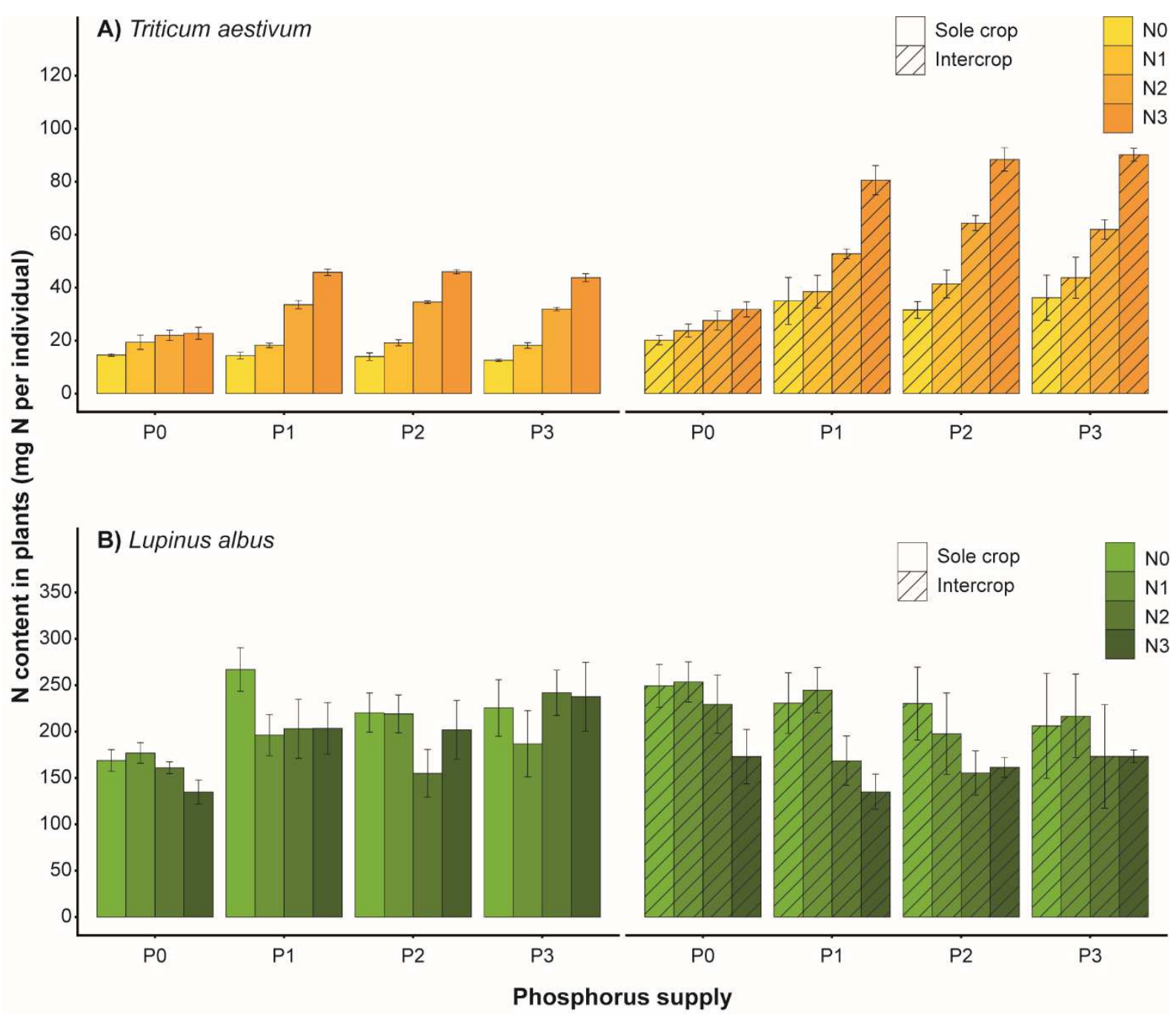

Figure 2. Nitrogen $(N)$ content in wheat $(A)$ and lupin $(B)$ at the end of the experiment. Vertical bars represent standard error. NO, N1, N2, N3 stand for the four levels of N supply, and PO, P1, P2, P3 stand for the four levels of P supply.

Phosphorus content

277 The total P content of wheat followed very similar trends to biomass. There was a significant effect of each of the two-way interactions between the three factors $(P<0.001$ for $N: P, N: T$ 
and P:T; Table 1, Fig. 3). Moreover, the main factors influenced P content almost identically to what we observed for biomass $(P<0.001$ for "N supply", "P supply" and "cropping" treatments), with a slightly greater effect of $\mathrm{P}$ supply $\left(\mathrm{Eta}^{2}=0.40\right.$; Table 1$)$.

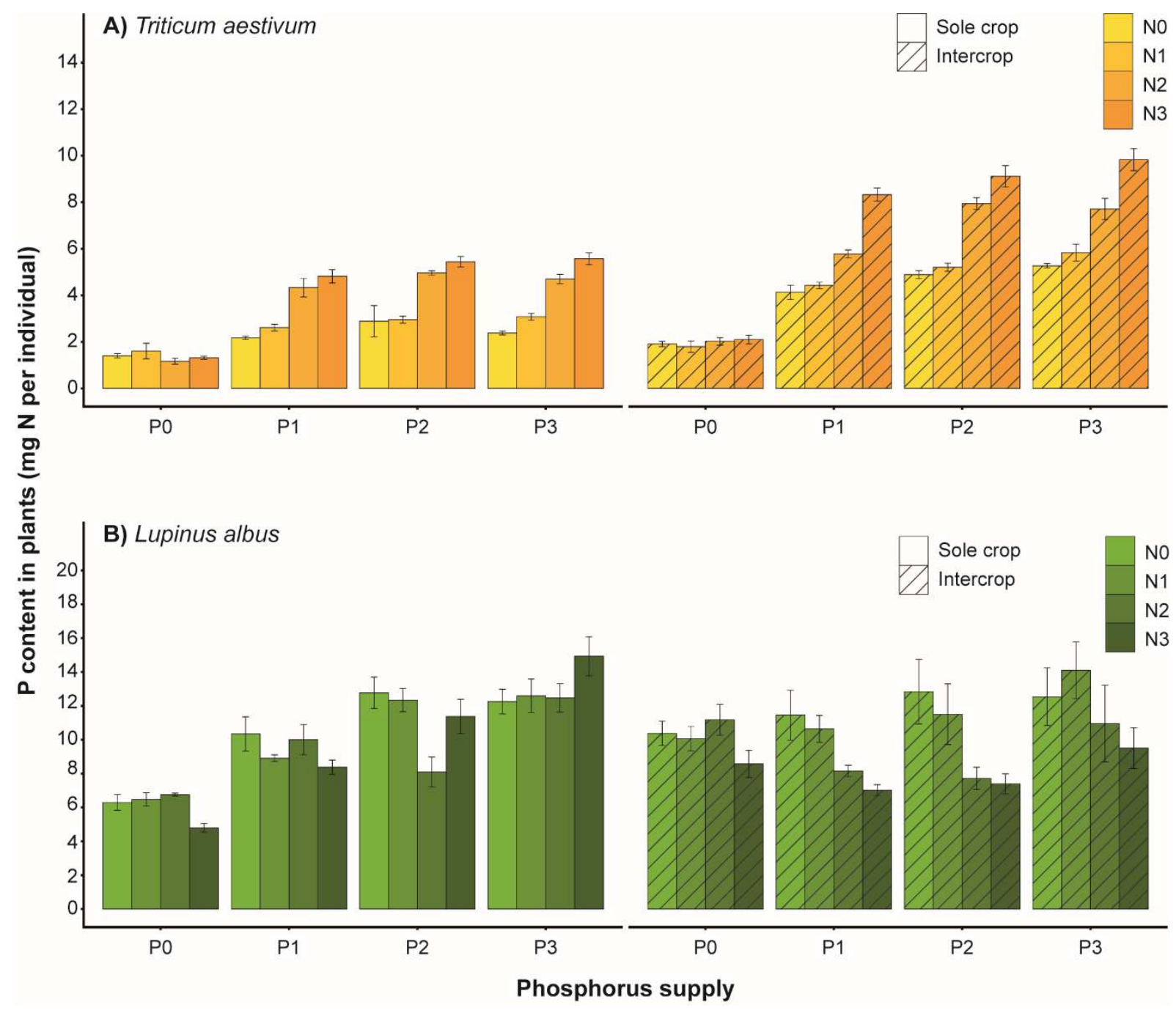

Figure 3. $P$ uptake by wheat (A) and lupin (B) at the end of the experiment. Vertical bars represent standard error. NO, N1, N2, $N 3$ stand for the four levels of $N$, and PO, P1, P2, P3 stand for the four levels of $P$.

There was also a significant effect for lupin of each of the three two-way interactions between the three factors $(P<0.05$ for $\mathrm{N}: \mathrm{P}, P<0.01$ for $\mathrm{N}: \mathrm{T}$ and $P<0.001$ for $\mathrm{P}: \mathrm{T}$;Table 1 , Fig. 3). The $\mathrm{P}$ content did not respond significantly to $\mathrm{N}$ supply in the sole crop treatment. However, it was negatively affected by $\mathrm{N}$ addition when lupin was intercropped with wheat (Table S1). In contrast, P supply had a strong positive effect in lupin grown alone, although it did not greatly influence lupin P content when intercropped with wheat. While no clear pattern emerged from the Tukey's range post hoc test results of the N:P interaction, the analysis of the main 
factors shows a strong positive effect of $P$ addition $\left(P<0.001, \mathrm{Eta}^{2}=0.25\right.$; Table 1$)$, and a negative effect of $\mathrm{N}$ addition $\left(P<0.001, \mathrm{Eta}^{2}=0.08\right)$ on lupin $\mathrm{P}$ content.

\section{Relative Yield of Mixture}

295

Intercropping significantly increased the total biomass of plants compared with sole cropping. At the scale of the complete experimental design, the value of $R Y M_{B}$ was $1.29 \pm 0.02$. Student's t-test showed that this value was significantly greater than $1\left(t_{79}=13.134, P<0.001\right)$, indicating a positive effect of intercropping on total biomass. This indicates that intercropping led, on average, to an increase of $\approx 29 \%$ of the total biomass produced by two wheat individuals and one lupin individual.

Similarly, plant $\mathrm{N}$ content $\left(R Y M_{N}=1.23 \pm 0.04\right)$ and $\mathrm{P}$ content $\left(R Y M_{P}=1.34 \pm 0.03\right)$ increased in intercropping compared with sole cropping, with values significantly greater than $1\left(t_{79}=\right.$ 5.734, $P<0.001$ and $t_{79}=11.647, P<0.001$ for $R Y M_{N}$ and $R Y M_{P}$, respectively).

Table 2. Two-way ANOVA and Eta-squared results for Relative yield of mixture (RYM) and Relative interaction intensity (RII) indices, with "N supply" and "P supply" as factors.

\begin{tabular}{|c|c|c|c|c|c|c|c|c|c|c|}
\hline & \multicolumn{6}{|c|}{ Relative yield of mixture (RYM) } & \multicolumn{4}{|c|}{ Relative interaction intensity (RII) } \\
\hline & \multicolumn{2}{|c|}{ Biomass } & \multicolumn{2}{|c|}{ Nitrogen } & \multicolumn{2}{|c|}{ Phosphorus } & \multicolumn{2}{|c|}{ Wheat } & \multicolumn{2}{|c|}{ Lupin } \\
\hline & $\bar{p}$ & $\mathrm{Eta}^{2}$ & $\bar{p}$ & $\mathrm{Eta}^{2}$ & $\bar{p}$ & $\mathrm{Eta}^{2}$ & $\bar{p}$ & $\mathrm{Eta}^{2}$ & $\bar{p}$ & $\mathrm{Eta}^{2}$ \\
\hline Main effects $N$ supply $(N)$ & 0.43 & 0.03 & 0.31 & 0.05 & 0.68 & 0.01 & 0.32 & 0.04 & 0.021 & 0.08 \\
\hline$P$ supply (P) & 0.07 & 0.09 & 0.08 & 0.09 & $<0.001$ & 0.33 & $<0.001$ & 0.27 & $<0.001$ & 0.37 \\
\hline Interactions $N: P$ & 0.23 & 0.14 & 0.46 & 0.11 & 0.05 & 0.15 & 0.57 & 0.08 & 0.38 & 0.08 \\
\hline
\end{tabular}

While the increase in biomass and $\mathrm{N}$ content were not significantly affected by $\mathrm{N}$ and $\mathrm{P}$ supply, we found a significant impact of $P$ supply on $\operatorname{RYMP}\left(P<0.001, \mathrm{Eta}^{2}=0.27\right.$; Table 2). Tukey's range post hoc showed a higher value of $R Y M P$ at P0 compared with other P levels (Table S2), indicating that the positive effect of intercropping on $\mathrm{P}$ content was significantly stronger at $\mathrm{PO}$ than at the other $\mathrm{P}$ levels.

\section{Relative Interaction Intensity}

At the species level, intercropping did not affect the total biomass of wheat and lupin in the same way. $R I I_{L}$ was not significantly different from 0 , as indicated by Student's t-test $\left(R I_{L}=-\right.$ $0.04 \pm 0.02, t_{79}=-1.65, P=0.104$; Fig. 4$)$, meaning that, at the scale of the complete experimental design, lupin total biomass did not significantly change when intercropped with wheat. 
In contrast, wheat total biomass generally increased when mixed with lupin. The $R / I_{w}$ index was positive and significantly different from $0\left(R / I_{W}=0.26 \pm 0.01, t_{79}=21.74, P<0.001\right.$; Fig. $4)$, indicating a general beneficial effect of intercropping on wheat biomass. This positive effect was not affected by $\mathrm{N}$ supply, but there was a strong effect of $\mathrm{P}$ treatment on $R /{ }_{W}(P<0.001$, $\mathrm{Eta}^{2}=0.27$; Table 2). More precisely, Tukey's range post hoc test showed a lower value for RIIW obtained at P0 compared with the other P levels (Table S2). This result shows that the benefit to wheat of intercropping with lupin was less at PO $(+45 \%$ increase of biomass per individual plant) compared with the three other P levels $(+72 \%,+77 \%$ and $+92 \%$ increase of biomass for P1, P2 and P3 levels, respectively).

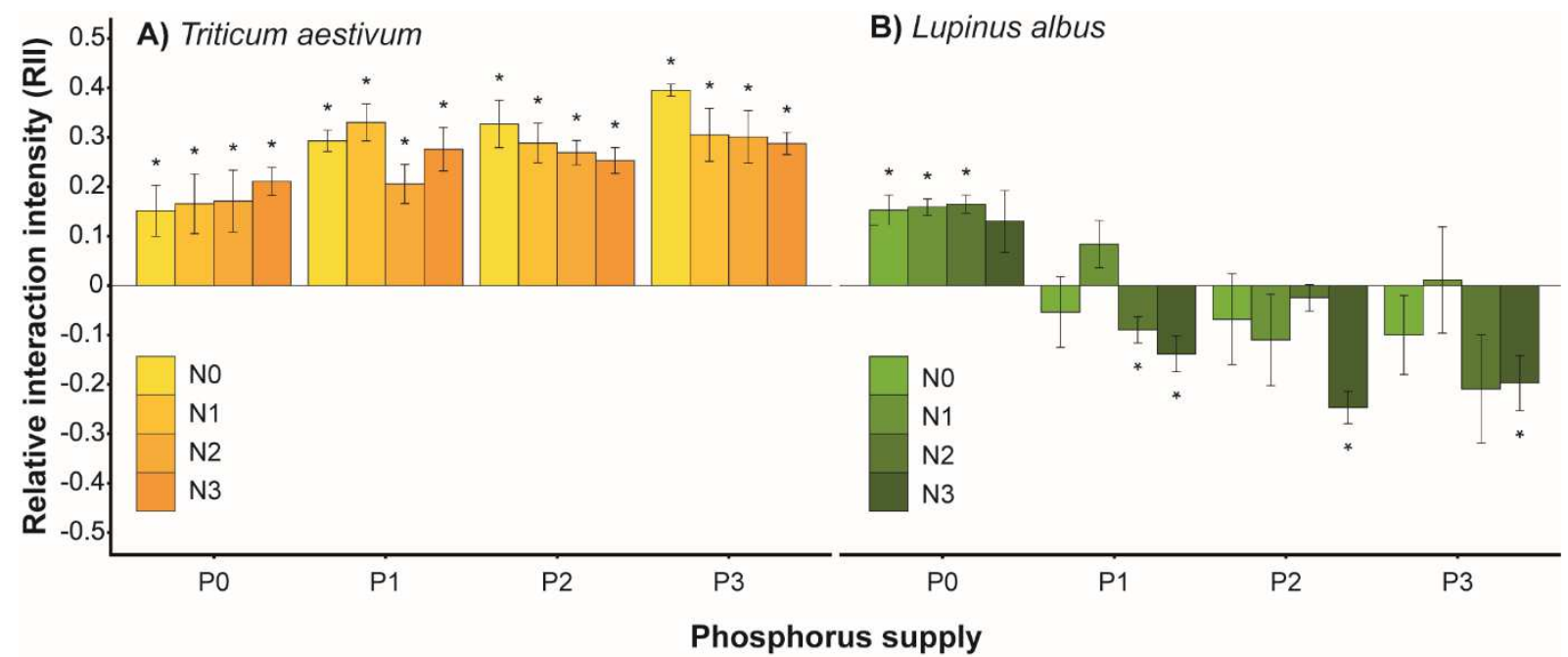

Figure 4. RII values of wheat (A) and lupin (B). Vertical bars represent standard error. NO, N1, N2, N3 stand for the four levels of $N$, and $P 0, P 1, P 2, P 3$ stand for the four levels of $P$. Stars $(*)$ denote RIl values significantly different from 0.

For lupin, the effect of intercropping on lupin total biomass depended on $\mathrm{N}$ and $\mathrm{P}$ treatments, although $R I I_{L}$ was not significantly different from 0 at the scale of the complete experimental design. First, $R I_{L}$ was strongly affected by $\mathrm{P}$ supply $\left(P<0.001, \mathrm{Eta}^{2}=0.37\right.$, see Table 2$)$, and Tukey's range post hoc test highlighted a higher value of the $R I_{L}$ obtained at P0 than at the three other P levels (Table S2). Furthermore, while $R I_{L}$ was significantly positive at PO $\left(t_{19}=\right.$ 8.788, $P<0.001)$, it was negative but not significantly different from 0 at $\mathrm{P} 1\left(t_{19}=-1.993, P=\right.$ $0.06)$, and negative and significantly different from 0 at P2 $\left(t_{19}=-3.054, P<0.01\right)$ and $\mathrm{P} 3\left(t_{19}=\right.$ $-2.671, P<0.05)$. Intercropping thus yielded a positive effect on lupin total biomass only at P0. Second, $R / I_{L}$ was also significantly affected by $N$ supply $\left(P<0.05\right.$, Eta ${ }^{2}=0.08$; Table 2$)$, and Tukey's range post hoc test showed a significant difference between the $R I_{L}$ obtained at N1 and the $R I_{L}$ obtained at N3 ( Table S2). No consistent trend of the effect of nutrient supply on lupin intercropped with wheat was apparent. However, Student's t-tests showed that N3 was 
the only level leading to a $R I I_{L}$ value significantly different from $0\left(t_{19}=-2.820, P<0.05\right)$, leading to a $21 \%$ decrease in lupin total biomass in the intercropping treatment.

Student's t-tests revealed a positive effect on wheat for every combination of $\mathrm{N}$ and $\mathrm{P}$ levels (Fig. 4). Intercropping significantly increased lupin biomass when grown at a low $P$ supply $\left(R I I_{L}\right.$ $>0$ in NOPO, N1PO and N2PO treatments). However, intercropping also significantly decreased lupin biomass at high $\mathrm{N}$ availability $\left(R I_{L}<0\right.$ in N2P1, N3P1, N3P2 and N3P3 treatments). For the other $\mathrm{N}$ and $\mathrm{P}$ combinations, intercropping did not significantly change lupin biomass.

\section{Changes in wheat-lupin interactions along $N$ and $P$ gradients}

Figure 5 shows the lupin and wheat total biomass obtained for each $\mathrm{N}$ and $\mathrm{P}$ combination in intercropping (two individuals of wheat and one individual of lupin). A color code illustrates the three types of lupin-wheat interactions, namely: mutualism $\left(R \|_{W}>0\right.$ and $\left.R I_{L}>0\right)$, facilitation of wheat by lupin $\left(R \|_{W}>0\right.$ and $\left.R I_{L}=0\right)$, and antagonistic competition $\left(R \|_{W}>0\right.$ and $\left.R / I_{L}<0\right)$.

The position along the nutrient gradients altered wheat-lupin interactions, from mutualism in the upper left corner of Fig. 5 - which corresponds to the most stressful conditions of our design - to antagonism at the bottom right corner of Fig. 5 - which corresponds to the least stressful conditions. More precisely, mutualistic interactions were observed in low-P treatments at all but the highest $\mathrm{N}$ supply (i.e. for NOP0, N1P0 and N2P0) while antagonistic interactions occurred in the N2P1 treatment and at high $\mathrm{N}$ treatments at all but the lowest $\mathrm{P}$ supply (i.e. for N3P1, N3P2 and N3P3). All other N and P combinations led to facilitation of wheat by lupin.

When considering the total biomass of wheat and lupin in regard to the nature of wheat/lupin interactions, it is clear that positive interactions (i.e. mutualism) are associated with the lowest values of wheat biomass, and negative interactions (i.e. competition) are associated with high wheat biomass. As stated above, lupin biomass was much less affected by $\mathrm{N}$ and $\mathrm{P}$ supply than wheat biomass. 


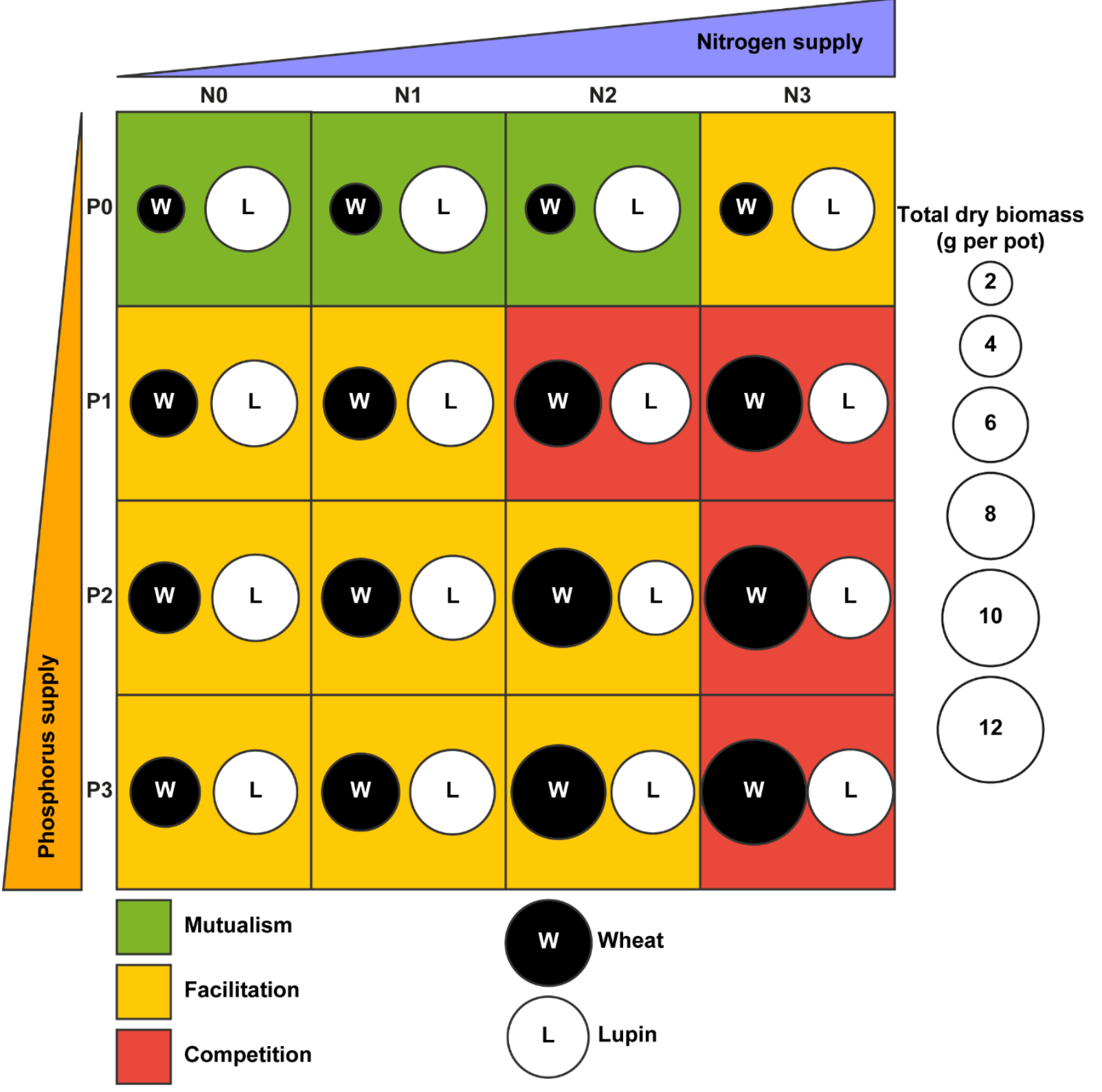

Figure 5. Circle colors designate the plant species (black for wheat and white for lupin), and circle surface areas are proportional to the total biomass of each species in the intercropping treatment (in $g$ of total dry biomass per pot). The background color corresponds with the nature of the interaction between wheat and lupin as defined by their RII (green for mutualism, yellow for facilitation of wheat by lupin, and red for competition)

Shoot:Root ratios

374 Wheat shoot to root biomass ratios (S:R) were significantly influenced by "N supply", "P 375 supply" and "cropping" treatments $\left(P<0.01\right.$, $\mathrm{Eta}^{2}=0.05, P<0.001, \mathrm{Eta}^{2}=0.40, P<.001, \mathrm{Eta}^{2}$ $=0.09$, respectively; Table 3).

When grown as a sole crop, wheat exhibited a higher S:R than when intercropped with lupin 378 (Table S3, Fig S1). In addition, although S:R increased with $\mathrm{N}$ addition, it decreased with 379 increasing P supply. Taken together, the highest wheat S:R were obtained in sole cropping at 
high $\mathrm{N}$ and low $\mathrm{P}$ supply, while the lowest wheat $\mathrm{S}: \mathrm{R}$ were obtained in intercropping at low $\mathrm{N}$ and high P supply. Cropping treatment was the only factor that significantly affected lupin $S: R$ (for lupin root biomass included all belowground parts, namely roots, cluster roots and nodules) $\left(P<0.001, \mathrm{Eta}^{2}=0.13\right)$. This was the opposite of the trend for wheat, where $\mathrm{S}: \mathrm{R}$ were greater in intercropping.

Table 3. Three-way ANOVA and Eta-squared results for the shoot to root ratio of wheat and lupin, fraction of belowground biomass as cluster roots and nodules in lupin, and percentages of nitrogen $(N)$ derived from atmosphere in lupin, with " $N$ supply", "P supply" and "cropping" treatments as factors.

\begin{tabular}{|c|c|c|c|c|c|c|c|c|c|c|c|}
\hline & & \multicolumn{4}{|c|}{ Shoot to root biomass ratio } & \multicolumn{4}{|c|}{$\begin{array}{l}\text { Fraction of belowground dry } \\
\text { biomass (\%) }\end{array}$} & \multirow{2}{*}{\multicolumn{2}{|c|}{$\begin{array}{c}\text { Nitrogen } \\
\text { derived from } \\
\text { atmosphere (\%) }\end{array}$}} \\
\hline & & \multicolumn{2}{|c|}{ Wheat } & \multicolumn{2}{|c|}{ Lupin } & \multicolumn{2}{|c|}{ Cluster roots } & \multicolumn{2}{|c|}{ Nodules } & & \\
\hline \multicolumn{2}{|c|}{ Main effects $N$ supply $(N)$} & 0.002 & 0.05 & 0.76 & $\overline{<0.01}$ & 0.20 & 0.02 & $<0.001$ & 0.28 & $<0.001$ & 0.37 \\
\hline & $P$ supply $(P)$ & $<0.001$ & 0.40 & 0.13 & 0.03 & $<0.001$ & 0.14 & $<0.001$ & 0.10 & $<0.001$ & 0.05 \\
\hline & Cropping Treatment ( $T)$ & $<0.001$ & 0.09 & $<0.001$ & 0.13 & 0.035 & 0.02 & $<0.001$ & 0.04 & $<0.001$ & 0.23 \\
\hline \multirow{3}{*}{ Interactions } & $N: T$ & 0.87 & $<0.01$ & 0.34 & 0.02 & 0.12 & 0.03 & 0.028 & 0.03 & $<0.001$ & 0.04 \\
\hline & $P: T$ & 0.71 & $<0.01$ & 0.46 & 0.02 & 0.53 & 0.01 & 0.37 & 0.01 & 0.024 & 0.02 \\
\hline & $N: P: T$ & 0.62 & 0.02 & 0.71 & 0.04 & 0.71 & 0.03 & 0.42 & 0.03 & 0.07 & 0.03 \\
\hline
\end{tabular}

\section{Biomass of cluster roots and nodules}

In lupin, the percentage of cluster roots $(\% C R)$ relative to the biomass of belowground parts, namely roots, cluster roots and nodules, was significantly affected by $P$ supply $\left(P<0.001\right.$, Eta ${ }^{2}$ $=0.14$, see Table 3). Tukey's range post hoc test showed a higher \%CR in lupin grown at P0 than at other P levels (Table S3, Fig. 6). There was also a small effect of cropping treatment on $\% C R\left(P<0.05, \mathrm{Eta}^{2}=0.02\right.$; Table 3). Tukey's range post hoc test showed a higher \%CR in lupin grown in sole cropping than in intercropping (Table S3, Fig. 6).

The percentage of nodules (\%nod) relative to the biomass of belowground parts was significantly impacted by the interaction between "N supply" and "cropping" $\left(P<0.05\right.$, Eta ${ }^{2}=$ 0.03; Table 3). Tukey's range post hoc test indicated that the decrease of \%nod with the addition of $\mathrm{N}$ was sharper in sole cropping than in intercropping treatments (Table S3). Moreover, $\mathrm{P}$ addition positively affected \%nod $\left(P<0.001, \mathrm{Eta}^{2}=0.10 ;\right.$ Tables 3 and S3). 


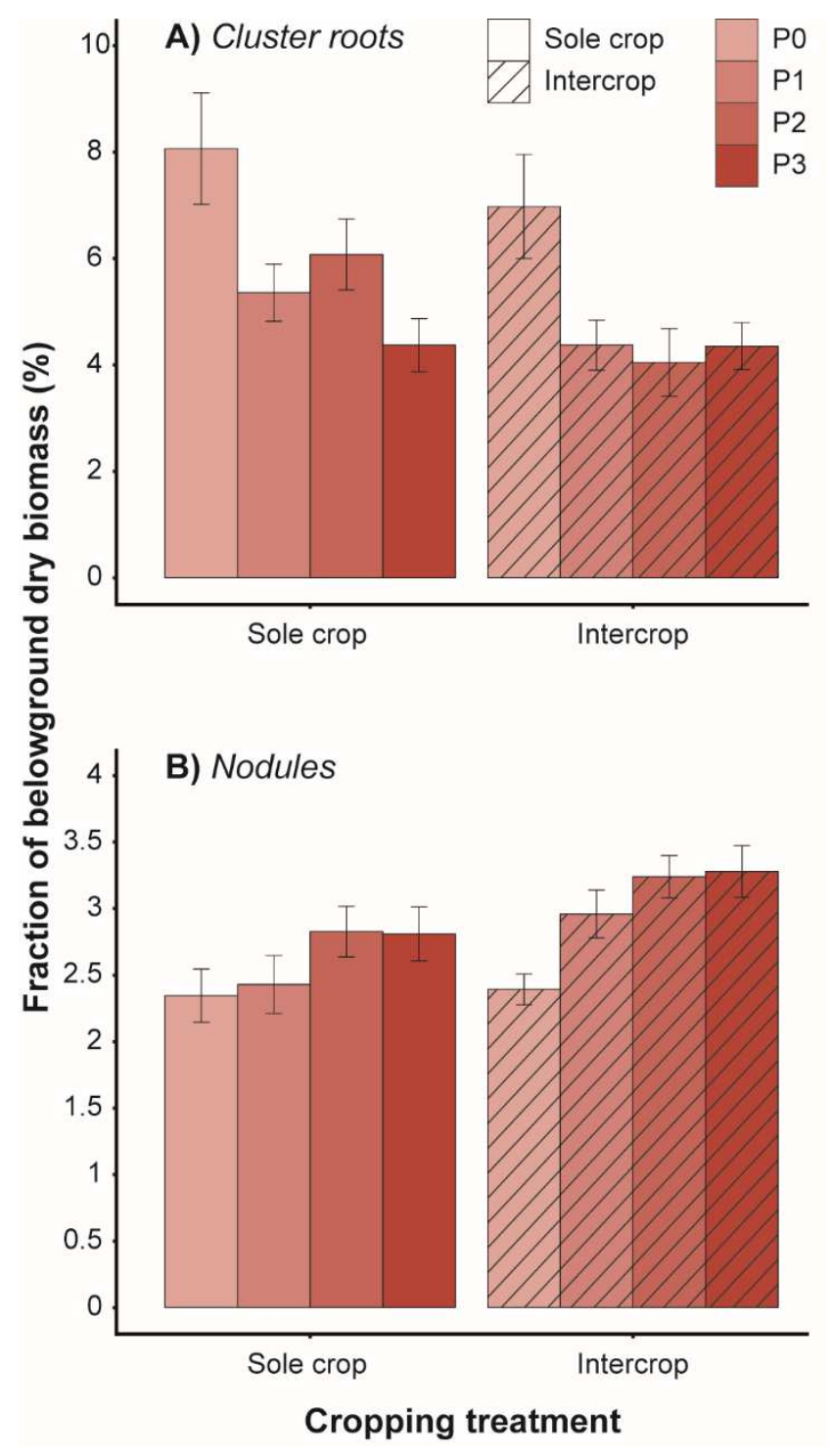

402 Figure 6. Fraction of belowground biomass as cluster roots (A) and nodules (B) in lupin. Vertical bars represent standard error. $403 P 0, P 1, P 2, P 3$ stand for the four levels of $P$ supply.

\section{$404 \quad \boldsymbol{N}$-fixation}

405

406

407

408

409

410

Percentages of $\mathrm{N}$ derived from the atmosphere $\left(\% \mathrm{Ndfa} a_{\text {Total }}\right)$ in lupin were significantly impacted by each of the three two-way interactions between the three factors, namely " $\mathrm{N}$ supply", "P supply" and "cropping" ( Table 3, Fig 7). While \%Ndfa $a_{\text {Total }}$ decreased with the addition of $\mathrm{N}$, this effect was stronger in lupins grown alone than when intercropped with wheat $\left(P<0.001, \mathrm{Eta}^{2}=0.04\right.$ for $\mathrm{N}: \mathrm{T}$ interaction; Table S3). In addition, the decrease of $\% N d f a_{T o t a l}$ with the addition of $\mathrm{N}$ was even more noticeable at low $\mathrm{P}$ supply $\left(P<0.001, \mathrm{Eta}^{2}=\right.$ 0.06 for $\mathrm{N}: \mathrm{P}$ interaction). Finally, while $\% N d f a_{T o t a l}$ was not significantly influenced by the addition of $\mathrm{P}$ in sole cropped lupins, it increased significantly in intercropped lupins $(P<0.05$, $\mathrm{Eta}^{2}=0.02$ for P:T interaction). Overall, \%Ndfa $a_{\text {Total }}$ decreased with $\mathrm{N}$ addition, but increased 
with P addition and in the intercropping treatment (Table S3), explaining $37 \%, 5 \%$ and $23 \%$ of the variation in \%Ndfa $a_{\text {Total }}$ for "N supply", "P supply" and "cropping" treatments, respectively, as shown by the analysis of main factors (Table 3 ).

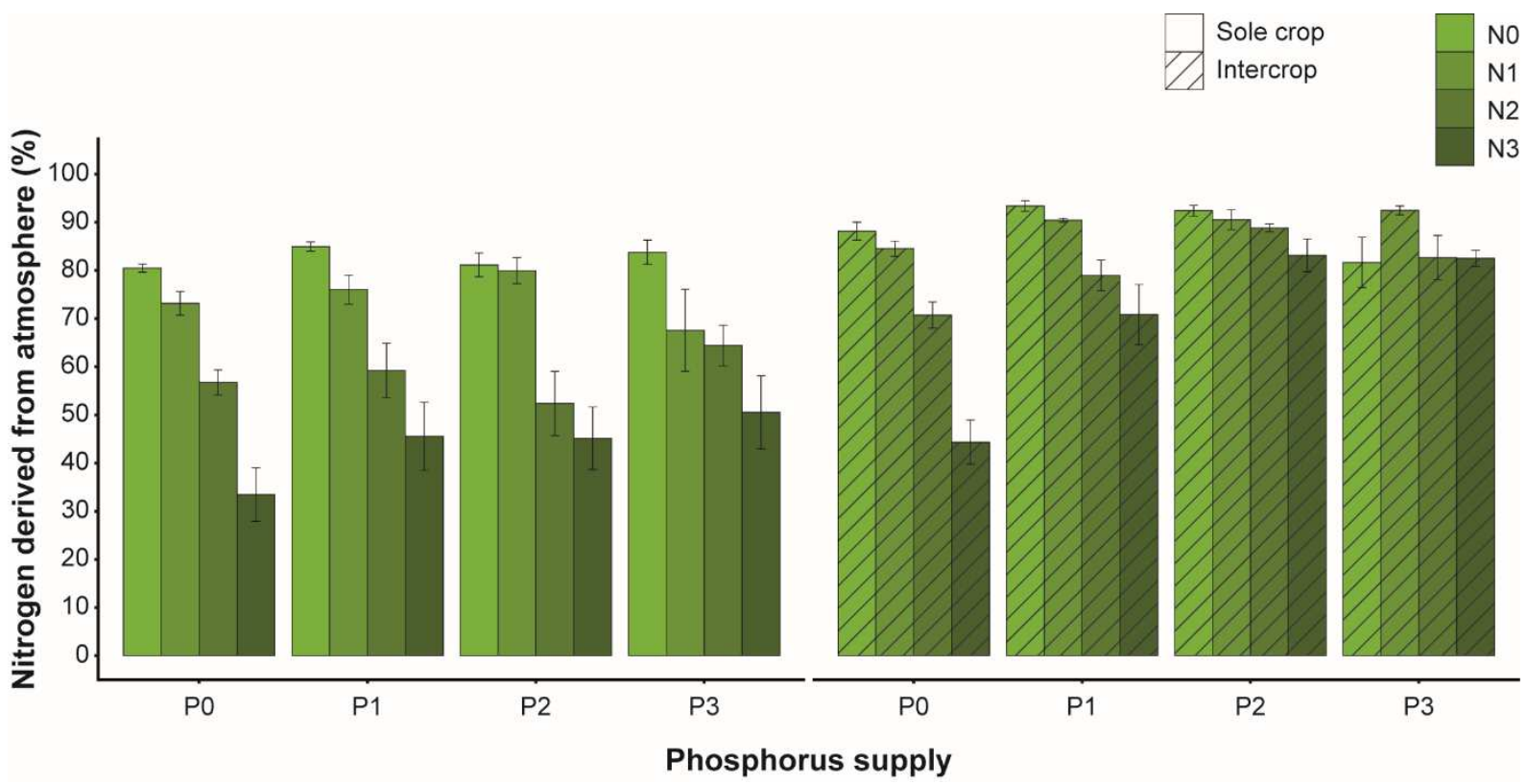

Figure 7. Percentages of nitrogen $(N)$ derived from the atmosphere in lupin. Vertical bars represent standard errors. NO, N1, $N 2, N 3$ stand for the four levels of $N$, and PO, P1, P2, P3 for the four levels of $P$.

\section{Discussion}

\section{Benefits of intercropping}

Intercropping of wheat with lupin always led to a substantial increase in total biomass, $\mathrm{N}$ content and P content compared to sole cropping. In addition, the increase in total biomass and $\mathrm{N}$ content was stable across the different combinations of $\mathrm{N}$ and $\mathrm{P}$ treatments, $R Y M_{B}$ and $R Y M_{N}$ not responding to $\mathrm{N}$ and $\mathrm{P}$ supply. This result is in line with the recent meta-analysis by Li et al. (2020), showing that intercropping can lead to large benefits under both low- and highinput conditions. The average value of $R Y M_{B}=1.29$, corresponding to a global gain of $29 \%$ in biomass, is in line with other studies comparing cereals and legumes grown separately versus intercropped, and confirms the general observation that intercropping markedly enhances plant growth (Bedoussac et al. 2015; Li et al. 2020; Tilman 2020). Similarly, the 23\% increase in $\mathrm{N}$ content matches results from previous studies showing a higher total $\mathrm{N}$ content in cereallegume intercropping than in sole cropping for equivalent plant densities and land surface areas (Bedoussac and Justes 2010; Hauggaard-Nielsen et al. 2009; Nyfeler et al. 2011). Regarding $R Y M P$, the $34 \%$ global increase in $\mathrm{P}$ content observed in intercropping is consistent 
with previous studies (Dissanayaka et al. 2015; Li et al. 2001). For example, Li et al. (2018) found an average increase in $\mathrm{P}$ acquisition of $28.4 \%$ and $27.6 \%$ in intercropped faba bean/maize and chickpea/maize, respectively, compared with their monocultures. However, the P-application rate did not influence this increase in that study, whereas in the present study there was a strong effect of $\mathrm{P}$ supply on $R Y M P$; PO led to a $39 \%$ increase in $\mathrm{P}$ content, while other P levels led to increases of about $25 \%$. This result highlights a P threshold effect between P0 (soil Olsen P level : $6.7 \mathrm{mg} \mathrm{P} \mathrm{kg}^{-1}$ ) and P1 (soil Olsen P level : $15.6 \mathrm{mg} \mathrm{P} \mathrm{kg}^{-1}$ ). This agrees with reports of critical soil P levels for wheat from 5 to $26 \mathrm{mg} \mathrm{kg}^{-1}$, depending on soil type and climate (Khan et al. 2018). Below this threshold, wheat was very strongly affected by $\mathrm{P}$ deficiency, inhibiting its response to the addition of $\mathrm{N}$.

\section{Changes in wheat-lupin interactions}

Although an overall positive effect of intercropping on total biomass was observed, this does not imply that the biomasses of wheat and lupin obtained in the intercrop treatment were greater for both species compared with the sole crop treatment. Cumulative biomass of both species was greater in the intercrop treatment, taking into account their relative individual densities. While RYM gives a good overall representation of the global effect of intercropping compared with sole cropping, it does not describe how each species is impacted, nor the magnitude of the change at the species level.

$R / l$ allows a better understanding at the species level. $R I_{L}$ gives a measure of the effect that intercropping had on lupin biomass; it was significantly positive only below the $\mathrm{P}$ threshold. Above the $P$ threshold, lupin was either not impacted (P1) or negatively impacted by wheat (P2 and P3). Consequently, the higher the $\mathrm{P}$ supply, the more negative the effect of intercropping on lupin total biomass. In contrast, $R / I_{W}$ - though always positive - was significantly greater above the $\mathrm{P}$ threshold than below. Concerning the influence of $\mathrm{N}$ supply on wheat-lupin interaction, RIIW was always positive and did not significantly vary with $\mathrm{N}$ supply. For lupin, for all $\mathrm{P}$ supply levels combined, there was a negative effect of intercropping on lupin biomass at the highest $\mathrm{N}$ level (N3) only, while other levels led to zero $R / I_{L}$. Taken together, a low $\mathrm{P}$ supply led to mutualistic interactions, while a high $\mathrm{N}$ supply led to antagonistic interactions. Although intercropping led to an increase in total biomass in all scenarios, we observed a change in the type of interaction along the $\mathrm{N}$ and $\mathrm{P}$ gradients, with mutualism under low-input conditions, facilitation of wheat by lupin under intermediate 
conditions, and antagonistic relationships under high-input conditions (Fig. 5). This pattern is in agreement with the stress gradient hypothesis (Brooker et al. 2008; Callaway 2007). This phenomenon has been widely described for various types of abiotic stress gradients such as aridity, elevation, or temperature mostly in natural ecosystems (He et al. 2013). In contrast, it has been seldom studied for $\mathrm{N}$ and $\mathrm{P}$ gradients in agroecosystems, and former studies have addressed $\mathrm{N}$ and P gradients separately: Tang et al. (2016) for instance did not validate the stress gradient hypothesis in a field experiment along the same P gradient as that tested in the present work. However, both theoretical and field studies have addressed the responses of plant communities to a switch from $\mathrm{N}$ to $\mathrm{P}$ limitation (Koffel et al. 2018; Laliberté et al. 2012).

\section{Underlying ecophysiological mechanisms of wheat-Iupin interactions}

While the relative increases in total biomass and $\mathrm{N}$ content were stable when lupin and wheat were intercropped, the changes in wheat-lupin interactions indicate that there was a compensation in biomass, $\mathrm{N}$ content, and $\mathrm{P}$ content variation between the two species along the $\mathrm{N}$ and $\mathrm{P}$ gradients. Indeed, responses in biomass, $\mathrm{N}$ content and $\mathrm{P}$ content tended to be opposite for wheat and lupin when intercropped (Figs 1, 2 and 3). This compensation mechanism has been identified in several intercropping studies (Jensen et al. 2020; Rao and Willey 1980) and is met "when the failure of one species is compensated by the other(s) because they differ in their sensitivity to abiotic stress", as described in a recent review by Justes et al. (2021).

In the present study, the lupin shoot to root ratio $(S: R)$ was not influenced by $N$ and $P$ supply. Instead, lupin adjusted the production of nodules and cluster roots in response to the various $\mathrm{N}$ and $\mathrm{P}$ combinations in our experimental setup. In contrast, wheat $\mathrm{S}: \mathrm{R}$ was strongly influenced by $N$ and $P$ treatments, decreasing with increasing $N$ supply. This result was expected, as it is well known that most plants, including wheat, decrease their allocation to roots with increasing $\mathrm{N}$ availability (Dreccer et al. 2000; Duncan et al. 2018; Reynolds and D'Antonio 1996). However, the observation of the highest $S: R$ at the lowest $P$ supply was unexpected. This underlines the strong limiting effect of the availability of $P$ below the $P$ threshold, in particular with regard to the production of root biomass. Indeed, we found that root biomass was particularly low at this level of $\mathrm{P}$ (data not shown). In addition, we observed a decreasing effect of intercropping on wheat $S: R$, whereas $S: R$ increased in intercropped 
lupin. These observations may reflect a competitive advantage of wheat over lupin in their ability to exploit the soil volume, particularly in a pot experiment where the soil volume is limited. Indeed, while belowground biomass of intercropped lupin tended to slightly decrease with increasing $\mathrm{N}$ supply (non-significantly), wheat more than doubled its root biomass when grown with the legume (data not shown). This result is supported by many studies describing the advantage in belowground competition that non-legumes have over legumes in moderately N-limited conditions (Bessler et al. 2012; Brooker et al. 2015; Jensen 1996; Jensen et al. 2020; White et al. 2013), including in wheat-white lupin intercropping systems (Mariotti et al. 2009). This is reflected here for lupin as the decrease in soil $N$ and P availability is promoting an increase in the production of nodules (\%nod) and symbiotic fixation (\%Ndfatotal), ultimately leading to a niche complementarity mechanism through the simultaneous exploitation of soil $\mathrm{N}$ by wheat and atmospheric $\mathrm{N}$ by lupin (Bedoussac et al. 2015; Justes et al. 2021). It is also interesting to note that $\mathrm{N}$ fixation and production of nodules were never totally suppressed, even at the highest supply of $\mathrm{N}$, though $\mathrm{N}$ availability did not affect lupin total biomass in the sole crop treatment. This observation indicates that $\mathrm{N}$ availability was always limiting in our experiment, even at the highest $\mathrm{N}$ supply, and that lupin was able to overcome $\mathrm{N}$ limitation through $\mathrm{N}$ fixation.

Lupin was able to mitigate $P$ limitation through the production of cluster roots, as their biomass, relative to total belowground biomass $(\% C R)$, was greater below the $\mathrm{P}$ threshold than above. Although there was a small negative effect of $P$ limitation on lupin total biomass, it was far less pronounced for lupin than for wheat. Moreover, the higher $\% C R$ observed at P0 than at other $\mathrm{P}$ levels suggests that cluster-root production has been promoted below this threshold, in agreement with previous studies showing an increase in cluster-root formation in low-P conditions (Keerthisinghe et al. 1998; Shen et al. 2003). In particular, this may explain the mutual benefits of intercropping in wheat and lupin below the $P$ threshold. Even though $P$ availability was too low to allow wheat to compete with lupin, the cereal benefited from the legume without harming it $\left(R I_{W}\right.$ and $\left.R I_{L}>0\right)$, and improved its $\mathrm{P}$ uptake as well as $\mathrm{N}$ uptake and total biomass. While numerous studies have shown facilitation from intercropping legumes in P-deficient soil, through their ability to acidify rhizosphere and release carboxylates and phosphatases (e.g. Cu et al. 2005; Hinsinger et al. 2011; Li et al. 2016, 2003), 
our results also show a facilitative effect from wheat at low $\mathrm{P}$ availability, leading to a mutualistic interaction between the cereal and the legume.

\section{Positive interactions or competition with positive consequences?}

If, as we hypothesized, the increase in $\mathrm{N}$ fixation when lupin was intercropped with wheat was due to a more efficient exploitation of soil $\mathrm{N}$ by wheat, thus stimulating the positive "niche complementarity" effect, we may have to change the way we consider positive interactions. Lupin's ability to fix $\mathrm{N}$ and solubilize sparingly-available $\mathrm{P}$ is controlled by nodules and cluster roots, respectively, whose production and activity both depend on $\mathrm{N}$ and $\mathrm{P}$ availability. When lupin was grown as a sole crop, $\mathrm{N}$ and $\mathrm{P}$ availability were determined by the levels we chose. However, when lupin was grown in mixture with wheat, $\mathrm{N}$ and $\mathrm{P}$ availability were determined not only by the supply we chose, but also by the impact of wheat on $\mathrm{N}$ and $\mathrm{P}$ availability. In turn, wheat modified the perception lupin had of its own chemical environment, leading to more pronounced responses to $\mathrm{N}$ and $\mathrm{P}$ deficiency. This is in line with the view of Bedoussac et al. (2015), who define interactions in multi-species mixtures as "the effect of one species on the environment and the response of the other(s) species to this change".

In the present experiment, when grown together, lupin was always beneficial to wheat since interspecific competition was less harmful than intraspecific competition (RIlw>0). For lupin, growth with wheat was beneficial below the $\mathrm{P}$ threshold, because wheat growth was so limited by $\mathrm{P}$ availability that it could not compete with lupin $\left(R I_{L}>0\right)$. Above the $\mathrm{P}$ threshold, and for a relatively low $\mathrm{N}$ availability, competition with wheat did not negatively affect lupin total biomass, because the legume compensated the drawbacks from being intercropped with wheat $\left(R I_{L}=0\right)$. However, at high $\mathrm{N}$ supply, and above the $\mathrm{P}$ threshold, growth conditions allowed wheat to outcompete lupin, leading to a decrease in biomass of the lupin in comparison with sole cropping $\left(R I_{L}<0\right)$. A simplistic explanation would be that lupin "helped" wheat to overcome $\mathrm{N}$ and $\mathrm{P}$ limitation through $\mathrm{N}$ fixation and increased $\mathrm{P}$ availability; however, it seems likely that the ability of lupin to "escape" the competition from wheat is most important. Therefore, the term "positive interaction" - which refers to niche complementarity for $\mathrm{N}$ and facilitation for $\mathrm{P}$ in our experiment - is misleading.

\section{Reconciling ecological intensification and production}


Wheat-lupin intercropping is a promising way to increase biomass production, particularly if wheat is the main crop. Whatever the supply of $\mathrm{N}$ and $\mathrm{P}$, wheat produced more biomass in intercropping than in sole cropping treatments. However, when comparing the least- with the most-productive treatments in intercropping, wheat total biomass increased more than fourfold (from 1.05 to $5.60 \mathrm{~g}$ dry matter plant ${ }^{-1}$ ). More precisely, biomass of wheat within mutualistic situations averaged $1.21 \mathrm{~g}$ dry matter plant ${ }^{-1}$, with means of 2.90 and $4.91 \mathrm{~g}$ dry matter plant ${ }^{-1}$ obtained in the cases of facilitation and competition, respectively. Consequently, though interactions tended to become positive as nutrient stress increased, wheat biomass was severely impacted when $\mathrm{N}$ and $\mathrm{P}$ were too severely limiting. Overall, our results confirm the claim from Tilman (2020), who developed the idea that "intercropping can bring the benefits of intensification within a reasonable footprint". This idea is partly based on the meta-analysis by Li et al. (2020) which demonstrates that intercropping can produce large yield increase in highly-fertilized systems. One challenge could be to find a balance between the use of chemical inputs and a satisfactory productivity.

\section{Conclusion}

Nitrogen and $P$ availability strongly influenced the nature of wheat-lupin interactions, changing from mutualism in low-input conditions to competition in high-input conditions. Despite this, our results show that intercropping always led to a significant increase of wheat biomass - even compensating the decrease of lupin biomass in competition scenarios - and to a better exploitation of $\mathrm{N}$ and $\mathrm{P}$ as a result of the ability of lupin to fix atmospheric $\mathrm{N}$ and increase $\mathrm{P}$ availability depending on $\mathrm{N}$ and $\mathrm{P}$ availability. Therefore, the intensification of ecological interactions through intercropping of legumes and cereals - even in highly fertilized situations - offers potential for sustainable crop production. There are obvious limitations to the present experiment in pots. For example, the root systems of both crops might not have interacted in the same way in the field as they did in our pots. Moreover, we only considered the vegetative stage of growth of wheat and lupin, while grain yield and $\mathrm{N}$ content are the main targets for farmers. Future studies carried out with a similar, combined $\mathrm{N}$ and $\mathrm{P}$ gradient design, in field conditions, with various crops and over the whole growth cycle would be a step forward in the design of ecologically intensive intercropping systems. 


\section{$\underline{\text { References }}$}

587

588

589

590

591

592

593

594

595

596

597

598

599

600

601

602

603

604

605

606

607

608

609

610

611

612

613

614

615

616

617

618

619

620

621

622

623

624
Altieri MA (1989) Agroecology: a new research and development paradigm for world agriculture. Agr Ecosyst Environ 27:37-46. https://doi.org/10.1016/0167-8809(89)90070-4

Armas C, Ordiales R, Pugnaire FI (2004) Measuring plant interactions: a new comparative index. Ecology 85:2682-2686. https://doi.org/10.1890/03-0650

Barot S, Allard V, Cantarel A, Enjalbert J, Gauffreteau A, Goldringer I, Lata JC, Le Roux X, Niboyet A, Porcher E (2017) Designing mixtures of varieties for multifunctional agriculture with the help of ecology. A review. Agron Sustain Dev 37:13. https://doi.org/10.1007/s13593-017-0418-x

Bedoussac L, Journet E-P, Hauggaard-Nielsen H, Naudin C, Corre-Hellou G, Jensen ES, Prieur L, Justes $E$ (2015) Ecological principles underlying the increase of productivity achieved by cereal-grain legume intercrops in organic farming. A review. Agron Sustain Dev 35:911-935.

https://doi.org/10.1007/s13593-014-0277-7

Bedoussac L, Justes $E$ (2010) Dynamic analysis of competition and complementarity for light and $N$ use to understand the yield and the protein content of a durum wheat-winter pea intercrop. Plant Soil 330:37-54. https://doi.org/10.1007/s11104-010-0303-8

Bessler H, Oelmann Y, Roscher C, Buchmann N, Scherer-Lorenzen M, Schulze E-D, Temperton VM, Wilcke W, Engels C (2012) Nitrogen uptake by grassland communities: contribution of N2 fixation, facilitation, complementarity, and species dominance. Plant Soil 358:301-322.

https://doi.org/10.1007/s11104-012-1181-z

Betencourt E, Duputel M, Colomb B, Desclaux D, Hinsinger P (2012) Intercropping promotes the ability of durum wheat and chickpea to increase rhizosphere phosphorus availability in a low $\mathrm{P}$ soil. Soil Biol Biochem 46:181-190. https://doi.org/10.1016/j.soilbio.2011.11.015

Brooker RW, Bennett AE, Cong W-F, Daniell TJ, George TS, Hallett PD, Hawes C, lannetta PPM, Jones HG, Karley AJ, Li L, McKenzie BM, Pakeman RJ, Paterson E, Schöb C, Shen J, Squire G, Watson CA, Zhang C, Zhang F, Zhang J, White PJ (2015) Improving intercropping: a synthesis of research in agronomy, plant physiology and ecology. New Phytol 206:107-117.

https://doi.org/10.1111/nph.13132

Brooker RW, Maestre FT, Callaway RM, Lortie CL, Cavieres LA, Kunstler G, Liancourt P, Tielboerger K, Travis JMJ, Anthelme F, Armas C, Coll L, Corcket E, Delzon S, Forey E, Kikvidze Z, Olofsson J, Pugnaire FI, Quiroz CL, Saccone P, Schiffers K, Seifan M, Touzard B, Michalet R (2008) Facilitation in plant communities: the past, the present, and the future. J Ecol 96:18-34. https://doi.org/10.1111/j.13652745.2007.01295.x

Callaway RM (1995) Positive interactions among plants. Bot Rev 61:306-349. https://doi.org/10.1007/BF02912621

Callaway RM (2007) Positive interactions and interdependence in plant communities. Springer Netherlands, Dordrecht

Colomb B, Debaeke P, Jouany C, Nolot JM (2007) Phosphorus management in low input stockless cropping systems: crop and soil responses to contrasting $P$ regimes in a 36-year experiment in southern France. Eur J Agron 26:154-165. https://doi.org/10.1016/j.eja.2006.09.004 
Cu STT, Hutson J, Schuller KA (2005) Mixed culture of wheat (Triticum aestivum L.) with white lupin (Lupinus albus L.) improves the growth and phosphorus nutrition of the wheat. Plant Soil 272:143151. https://doi.org/10.1007/s11104-004-4336-8

Dissanayaka DMSB, Maruyama H, Masuda G, Wasaki J (2015) Interspecific facilitation of P acquisition in intercropping of maize with white lupin in two contrasting soils as influenced by different rates and forms of P supply. Plant Soil 390:223-236. https://doi.org/10.1007/s11104-015-2392-x

Dreccer MF, Schapendonk AHCM, Slafer GA, Rabbinge R (2000) Comparative response of wheat and oilseed rape to nitrogen supply: absorption and utilisation efficiency of radiation and nitrogen during the reproductive stages determining yield. Plant Soil 220:189-205.

https://doi.org/10.1023/A:1004757124939

Duncan EG, O'Sullivan CA, Roper MM, Palta J, Whisson K, Peoples MB (2018) Yield and nitrogen use efficiency of wheat increased with root length and biomass due to nitrogen, phosphorus, and potassium interactions. J Plant Nutr Soil Sc 181:364-373. https://doi.org/10.1002/jpln.201700376

Duru M, Therond O, Martin G, Martin-Clouaire R, Magne M-A, Justes E, Journet E-P, Aubertot J-N, Savary S, Bergez J-E, Sarthou JP (2015) How to implement biodiversity-based agriculture to enhance ecosystem services: a review. Agron Sustain Dev 35:1259-1281. https://doi.org/10.1007/s13593015-0306-1

FAO (2014) World reference base for soil resources 2014: international soil classification system for naming soils and creating legends for soil maps. FAO, Rome, Italy

FAO (2021) Crop prospects and food situation \#4, december 2021: quarterly global report. FAO, Rome, Italy

Foley JA, Ramankutty N, Brauman KA, Cassidy ES, Gerber JS, Johnston M, Mueller ND, O'Connell C, Ray DK, West PC, Balzer C, Bennett EM, Carpenter SR, Hill J, Monfreda C, Polasky S, Rockström J, Sheehan J, Siebert S, Tilman D, Zaks DPM (2011) Solutions for a cultivated planet. Nature 478:337342. https://doi.org/10.1038/nature10452

Gaba S, Lescourret F, Boudsocq S, Enjalbert J, Hinsinger P, Journet E-P, Navas M-L, Wery J, Louarn G, Malézieux E, Pelzer E, Prudent M, Ozier-Lafontaine $H$ (2015) Multiple cropping systems as drivers for providing multiple ecosystem services: from concepts to design. Agron Sustain Dev 35:607-623. https://doi.org/10.1007/s13593-014-0272-z

Gardner WK, Boundy KA (1983) The acquisition of phosphorus by Lupinus albus L. IV. The effect of interplanting wheat and white lupin on the growth and mineral composition of the two species. Plant Soil 70:391-402. http://sci-hub.tw/10.1007/BF02374894

Gardner WK, Parbery DG, Barber DA (1981) Proteoid root morphology and function in Lupinus albus. Plant Soil 60:143-147. https://doi.org/10.1007/BF02377120

Hauggaard-Nielsen H, Gooding M, Ambus P, Corre-Hellou G, Crozat Y, Dahlmann C, Dibet A, von Fragstein P, Pristeri A, Monti M, Jensen ES (2009) Pea-barley intercropping for efficient symbiotic $\mathrm{N} 2$-fixation, soil $\mathrm{N}$ acquisition and use of other nutrients in European organic cropping systems. Field Crop Res 113:64-71. https://doi.org/10.1016/j.fcr.2009.04.009

He Q, Bertness MD, Altieri AH (2013) Global shifts towards positive species interactions with increasing environmental stress. Ecol Lett 16:695-706. https://doi.org/10.1111/ele.12080 
Hinsinger $P$ (2001) Bioavailability of soil inorganic $P$ in the rhizosphere as affected by root-induced chemical changes: a review. Plant Soil 237:173-195. https://doi.org/10.1023/A:1013351617532

Hinsinger P, Betencourt E, Bernard L, Brauman A, Plassard C, Shen J, Tang X, Zhang F (2011) P for two, sharing a scarce resource: soil phosphorus acquisition in the rhizosphere of intercropped species. Plant Physiol 156:1078-1086. https://doi.org/10.1104/pp.111.175331

Jensen ES (1996) Grain yield, symbiotic N2 fixation and interspecific competition for inorganic $\mathrm{N}$ in pea-barley intercrops. Plant Soil 182:25-38. https://doi.org/10.1007/BF00010992

Jensen ES, Carlsson G, Hauggaard-Nielsen H (2020) Intercropping of grain legumes and cereals improves the use of soil $\mathrm{N}$ resources and reduces the requirement for synthetic fertilizer $\mathrm{N}$ : a globalscale analysis. Agron Sustain Dev 40:5. https://doi.org/10.1007/s13593-020-0607-x

Justes E, Bedoussac L, Dordas C, Frak E, Louarn G, Boudsocq S, Journet E-P, Lithourgidis A, Pankou C, Zhang C, Carlsson G, Jensen ES, Watson C, Li L (2021) The 4C approach as a way to understand species interactions determining intercropping productivity. Front Agric Sci Eng 8:387-399. https://doi.org/10.15302/J-FASE-2021414

Kahmen A, Renker C, Unsicker SB, Buchmann N (2006) Niche complementarity for nitrogen: an explanation for the biodiversity and ecosystem functioning relationship? Ecology 87:1244-1255. https://doi.org/10.1890/0012-9658(2006)87[1244:NCFNAE]2.0.CO;2

Keerthisinghe G, Hocking PJ, Ryan PR, Delhaize E (1998) Effect of phosphorus supply on the formation and function of proteoid roots of white lupin (Lupinus albus L.). Plant Cell Environ 21:467478. https://doi.org/10.1046/j.1365-3040.1998.00300.x

Khan A, Lu G, Ayaz M, Zhang H, Wang R, Lv F, Yang X, Sun B, Zhang S (2018) Phosphorus efficiency, soil phosphorus dynamics and critical phosphorus level under long-term fertilization for single and double cropping systems. Agr Ecosyst Environ 256:1-11. https://doi.org/10.1016/j.agee.2018.01.006

Koffel T, Boudsocq S, Loeuille N, Daufresne T (2018) Facilitation- vs. competition-driven succession: the key role of resource-ratio. Ecol Lett 21:1010-1021. https://doi.org/10.1111/ele.12966

Laliberté E, Turner BL, Costes T, Pearse SJ, Wyrwoll K-H, Zemunik G, Lambers H (2012) Experimental assessment of nutrient limitation along a 2-million-year dune chronosequence in the south-western Australia biodiversity hotspot. J Ecol 100:631-642. https://doi.org/10.1111/j.13652745.2012.01962.x

Lambers H (2022) Phosphorus acquisition and utilization in plants. Annu Rev Plant Biol 73:. https://doi.org/10.1146/annurev-arplant-102720-125738

Lambers H, Shane MW, Cramer MD, Pearse SJ, Veneklaas EJ (2006) Root structure and functioning for efficient acquisition of phosphorus: matching morphological and physiological traits. Ann Bot 98:693-713. https://doi.org/10.1093/aob/mcl114

Li C, Dong Y, Li H, Shen J, Zhang F (2016) Shift from complementarity to facilitation on P uptake by intercropped wheat neighboring with faba bean when available soil P is depleted. Sci Rep 6:18663. https://doi.org/10.1038/srep18663

Li C, Hoffland E, Kuyper TW, Yu Y, Zhang C, Li H, Zhang F, van der Werf W (2020) Syndromes of production in intercropping impact yield gains. Nat Plants 6:653-660.

https://doi.org/10.1038/s41477-020-0680-9 
Li L, Sun J, Zhang F, Li X, Yang S, Rengel Z (2001) Wheat/maize or wheat/soybean strip intercropping: I. Yield advantage and interspecific interactions on nutrients. Field Crop Res 71:123-137. https://doi.org/10.1016/S0378-4290(01)00156-3

Li L, Tang C, Rengel Z, Zhang F (2003) Chickpea facilitates phosphorus uptake by intercropped wheat from an organic phosphorus source. Plant Soil 248:297-303.

https://doi.org/10.1023/A:1022389707051

Li L, Tilman D, Lambers H, Zhang F-S (2014) Plant diversity and overyielding: insights from belowground facilitation of intercropping in agriculture. New Phytol 203:63-69. https://doi.org/10.1111/nph.12778

Li X-F, Wang C-B, Zhang W-P, Wang L-H, Tian X-L, Yang S-C, Jiang W-L, van Ruijven J, Li L (2018) The role of complementarity and selection effects in $\mathrm{P}$ acquisition of intercropping systems. Plant Soil 422:479-493. https://doi.org/10.1007/s11104-017-3487-3

Li Y-Y, Yu C-B, Cheng X, Li C-J, Sun J-H, Zhang F-S, Lambers H, Li L (2009) Intercropping alleviates the inhibitory effect of $\mathrm{N}$ fertilization on nodulation and symbiotic $\mathrm{N} 2$ fixation of faba bean. Plant Soil 323:295-308. https://doi.org/10.1007/s11104-009-9938-8

Loreau M, Hector A (2001) Partitioning selection and complementarity in biodiversity experiments. Nature 412:72-76. https://doi.org/10.1038/35083573

Malézieux E (2012) Designing cropping systems from nature. Agron Sustain Dev 32:15-29. https://doi.org/10.1007/s13593-011-0027-z

Mariotti M, Masoni A, Ercoli L, Arduini I (2009) Above- and below-ground competition between barley, wheat, lupin and vetch in a cereal and legume intercropping system. Grass Forage Sci 64:401412. https://doi.org/10.1111/j.1365-2494.2009.00705.x

Martin-Guay M-O, Paquette A, Dupras J, Rivest D (2018) The new green revolution: sustainable intensification of agriculture by intercropping. Sci Total Environ 615:767-772.

https://doi.org/10.1016/j.scitotenv.2017.10.024

Nyfeler D, Huguenin-Elie O, Suter M, Frossard E, Lüscher A (2011) Grass-legume mixtures can yield more nitrogen than legume pure stands due to mutual stimulation of nitrogen uptake from symbiotic and non-symbiotic sources. Agr Ecosyst Environ 140:155-163.

https://doi.org/10.1016/j.agee.2010.11.022

Rao MR, Willey RW (1980) Evaluation of yield stability in intercropping: studies on sorghum/pigeonpea. Exp Agr 16:105-116. https://doi.org/10.1017/S0014479700010796

Reynolds HL, D'Antonio C (1996) The ecological significance of plasticity in root weight ratio in response to nitrogen: opinion. Plant Soil 185:75-97. https://doi.org/10.1007/BF02257566

Sauvadet M, Trap J, Damour G, Plassard C, Van den Meersche K, Achard R, Allinne C, Autfray P, Bertrand I, Blanchart E, Deberdt P, Enock S, Essobo J-D, Freschet GT, Hedde M, de Melo Virginio Filho E, Rabary B, Rakotoarivelo M, Randriamanantsoa R, Rhino B, Ripoche A, Rosalie E, Saj S, Becquer T, Tixier P, Harmand J-M (2021) Agroecosystem diversification with legumes or non-legumes improves differently soil fertility according to soil type. Sci Total Environ 795:148934. https://doi.org/10.1016/j.scitotenv.2021.148934 
Shen J, Rengel Z, Tang C, Zhang F (2003) Role of phosphorus nutrition in development of cluster roots and release of carboxylates in soil-grown Lupinus albus. Plant Soil 248:199-206.

https://doi.org/10.1023/A:1022375229625

Steffen W, Richardson K, Rockström J, Cornell SE, Fetzer I, Bennett EM, Biggs R, Carpenter SR, Vries W de, Wit CA de, Folke C, Gerten D, Heinke J, Mace GM, Persson LM, Ramanathan V, Reyers B, Sörlin $S$ (2015) Planetary boundaries: guiding human development on a changing planet. Science(At: https://www.science.org/doi/abs/10.1126/science.1259855. Accessed: 7/2/2022). https://doi.org/10.1126/science.1259855

Tang X, Placella SA, Daydé F, Bernard L, Robin A, Journet E-P, Justes E, Hinsinger P (2016) Phosphorus availability and microbial community in the rhizosphere of intercropped cereal and legume along a Pfertilizer gradient. Plant Soil 407:119-134. https://doi.org/10.1007/s11104-016-2949-3

Tilman D (2020) Benefits of intensive agricultural intercropping. Nat Plants 6:604-605. https://doi.org/10.1038/s41477-020-0677-4

Tilman D, Fargione J, Wolff B, D'Antonio C, Dobson A, Howarth R, Schindler D, Schlesinger WH, Simberloff D, Swackhamer D (2001) Forecasting agriculturally driven global environmental change. Science 292:281-284. https://doi.org/10.1126/science.1057544

Unkovich MJ, Herridge DF, People MB, Cadish G, Boddey B, Giller K, Alves BJR, Chalk PM (2008) Measuring plant-associated nitrogen fixation in agricultural systems. Australian Centre for International Agricultural Research. Canberra

White PJ, George TS, Gregory PJ, Bengough AG, Hallett PD, McKenzie BM (2013) Matching roots to their environment. Ann Bot 112:207-222. https://doi.org/10.1093/aob/mct123

Wilson JB (1988) Shoot competition and root competition. J Appl Ecol 25:279-296. https://doi.org/10.2307/2403626

Yu R-P, Lambers H, Callaway RM, Wright AJ, Li L (2021) Belowground facilitation and trait matching: two or three to tango? Trends Plant Sci 26:1227-1235. https://doi.org/10.1016/j.tplants.2021.07.014

\section{Statements \& Declarations}

\section{Funding}

This work was supported by a "Pari Scientifique" funding from Agroecosystem Department, INRAE, 2015.

\section{Conflicts of interest/Competing interests}

The authors have no relevant financial or non-financial interests to disclose.

\section{Availability of data and material}


777 The datasets generated during and/or analyzed during the current study are available from 778 the corresponding author on reasonable request.

\section{Authors' contributions}

780 Simon Boudsocq, Philippe Hinsinger and Hans Lambers contributed to the study conception 781 and design. Material preparation, data collection and analysis were performed by Simon 782 Boudsocq and Camille Cros. The first draft of the manuscript was written by Simon Boudsocq 783 and all authors commented on previous versions of the manuscript. All authors read and 784 approved the final manuscript.

785 
Table S1. Total dry biomass, nitrogen (N) content and phosphorus (P) content; means \pm standard errors of wheat and lupin in

788 different treatments. Only factors and interaction between factors having a significant effect are shown. Within a column,

789 different letters denote significant difference $(P<0.05)$.

\begin{tabular}{|c|c|c|c|c|c|c|c|c|c|}
\hline & & & \multicolumn{2}{|c|}{$\begin{array}{c}\text { Total dry biomass per individual } \\
\text { (g) }\end{array}$} & \multicolumn{3}{|c|}{$\begin{array}{c}\text { Nitrogen content } \\
\text { (mg N per individual) }\end{array}$} & \multicolumn{2}{|c|}{$\begin{array}{l}\text { Phosphorus content } \\
\text { (mg P per individual) }\end{array}$} \\
\hline & & & Wheat & Lupin & Wheat & & Lupin & Wheat & Lupin \\
\hline \multirow[t]{4}{*}{$\bar{N}$} & & NO & $2.18 \pm 0.17 \mathrm{a}$ & & $22.4 \pm 2.1$ & $\bar{a}$ & $223.6 \pm 11.4 b$ & $3.12 \pm 0.24 \mathrm{a}$ & $11.12 \pm 0.52 b$ \\
\hline & & $N 1$ & $2.61 \pm 0.20 b$ & & $27.8 \pm 2.2$ & $b$ & $211.1 \pm 10.8 \mathrm{ab}$ & $3.44 \pm 0.25 a$ & $10.88 \pm 0.51 b$ \\
\hline & & N2 & $3.78 \pm 0.31 c$ & & $41.1 \pm 2.5$ & c & $186.0 \pm 11.2 \mathrm{ab}$ & $4.83 \pm 0.37 b$ & $9.48 \pm 0.46 a$ \\
\hline & & N3 & $4.48 \pm 0.37 d$ & & $56.1 \pm 4.1$ & d & $177.7 \pm 9.4 \quad a$ & $5.82 \pm 0.48 c$ & $8.99 \pm 0.53 \quad$ a \\
\hline \multirow[t]{4}{*}{$P$} & & $P O$ & $1.31 \pm 0.07 \mathrm{a}$ & & $22.8 \pm 1.1$ & $a$ & & $1.67 \pm 0.08 \mathrm{a}$ & $8.10 \pm 0.41$ a \\
\hline & & $P 1$ & $3.59 \pm 0.24 b$ & & $42.1 \pm 3.6$ & b & & $4.71 \pm 0.32 b$ & $9.25 \pm 0.33 a b$ \\
\hline & & $P 2$ & $4.18 \pm 0.30 \mathrm{c}$ & & $42.4 \pm 3.8$ & $b$ & & $5.43 \pm 0.34 c$ & $10.50 \pm 0.51 b$ \\
\hline & & P3 & $4.09 \pm 0.31 c$ & & $42.3 \pm 4.0$ & $b$ & & $5.55 \pm 0.37 c$ & $12.42 \pm 0.52 c$ \\
\hline \multirow{2}{*}{$T$} & Sole C & Crop & $2.37 \pm 0.13 a$ & & $26.1 \pm 1.4$ & $a$ & & $3.24 \pm 0.18 a$ & \\
\hline & Interc & crop & $4.20 \pm 0.24 b$ & & $48.3 \pm 2.7$ & b & & $5.42 \pm 0.30 \mathrm{~b}$ & \\
\hline \multirow[t]{16}{*}{$N: P$} & & $P O$ & $1.15 \pm 0.09 \mathrm{a}$ & & $17.4 \pm 1.3$ & $\mathrm{a}$ & & $1.66 \pm 0.11 \mathrm{a}$ & $8.34 \pm 0.79$ abcd \\
\hline & & $P 1$ & $2.37 \pm 0.28 b$ & & $26.1 \pm 6.3$ & $a b$ & & $3.15 \pm 0.40 \mathrm{~b}$ & $10.90 \pm 0.86$ bcdefg \\
\hline & NO & $P 2$ & $2.68 \pm 0.32 b$ & & $22.8 \pm 3.4$ & $a b$ & & $3.89 \pm 0.47 b c$ & $12.81 \pm 1.00 \mathrm{fg}$ \\
\hline & & P3 & $2.57 \pm 0.35 b$ & & $24.4 \pm 5.6$ & $a b$ & & $3.83 \pm 0.49 b c$ & $12.40 \pm 0.87 \mathrm{efg}$ \\
\hline & & PO & $1.38 \pm 0.19 a$ & & $21.6 \pm 1.9$ & $a b$ & & $1.70 \pm 0.20 \mathrm{a}$ & $8.27 \pm 0.71 a b c$ \\
\hline & $N 1$ & P1 & $2.76 \pm 0.35 b$ & & $28.4 \pm 4.8$ & $a b$ & & $3.52 \pm 0.35 b c$ & $9.78 \pm 0.51$ abcdefg \\
\hline & $N A$ & $P 2$ & $3.16 \pm 0.32 b$ & & $30.3 \pm 4.5$ & $b$ & & $4.08 \pm 0.39 b c$ & $11.92 \pm 0.92$ defg \\
\hline & & P3 & $3.19 \pm 0.37 b c$ & & $31.0 \pm 5.6$ & bc & & $4.46 \pm 0.49 \mathrm{~cd}$ & $13.34 \pm 0.96 \mathrm{~g}$ \\
\hline & & PO & $1.27 \pm 0.10 \mathrm{a}$ & & $24.8 \pm 2.1$ & $a b$ & & $1.60 \pm 0.17 \mathrm{a}$ & $9.21 \pm 0.91$ abcde \\
\hline & 2 & P1 & $3.96 \pm 0.30 \mathrm{~cd}$ & & $43.2 \pm 3.4$ & $\mathrm{~cd}$ & & $5.05 \pm 0.32 d$ & $9.08 \pm 0.54$ abcde \\
\hline & NOL & $P 2$ & $5.18 \pm 0.50$ ef & & $49.5 \pm 5.1$ & d & & $6.46 \pm 0.51$ ef & $7.91 \pm 0.52 a b$ \\
\hline & & P3 & $4.72 \pm 0.57 \mathrm{de}$ & & $47.0 \pm 5.3$ & d & & $6.21 \pm 0.55 \mathrm{e}$ & $11.71 \pm 1.17$ cdefg \\
\hline & & PO & $1.43 \pm 0.14 a$ & & $27.3 \pm 2.3$ & $a b$ & & $1.71 \pm 0.16 a$ & $6.68 \pm 0.75 a$ \\
\hline & $N 13$ & $P 1$ & $4.85 \pm 0.48 \mathrm{e}$ & & $63.2 \pm 6.4$ & e & & $6.57 \pm 0.61$ ef & $7.70 \pm 0.34 a b$ \\
\hline & & $P 2$ & $5.74 \pm 0.57 \mathrm{f}$ & & $67.2 \pm 7.4$ & e & & $7.28 \pm 0.66 \mathrm{fg}$ & $9.38 \pm 0.86$ abcdef \\
\hline & & P3 & $5.89 \pm 0.61 f$ & & $67.0 \pm 7.8$ & e & & $7.70 \pm 0.75 \mathrm{~g}$ & $12.2 \pm 1.20$ efg \\
\hline \multirow[t]{8}{*}{$N: T$} & & NO & $1.49 \pm 0.08 a$ & $7.78 \pm 0.33 a b$ & $13.8 \pm 0.5$ & $a$ & & $2.21 \pm 0.21 \mathrm{a}$ & $10.42 \pm 0.71 \mathrm{abc}$ \\
\hline & Sole & N1 & $1.85 \pm 0.12 a$ & $7.43 \pm 0.32 a b$ & $18.8 \pm 0.8$ & a & & $2.56 \pm 0.17 a$ & $10.14 \pm 0.68 \mathrm{abc}$ \\
\hline & Crop & N2 & $2.81 \pm 0.25 b$ & $7.16 \pm 0.35 a b$ & $30.6 \pm 1.3$ & $b$ & & $3.79 \pm 0.37 b$ & $9.47 \pm 0.62 a b$ \\
\hline & & N3 & $3.28 \pm 0.31 \mathrm{bc}$ & $8.06 \pm 0.41 b$ & $39.6 \pm 2.3$ & c & & $4.29 \pm 0.41 \mathrm{~b}$ & $9.87 \pm 0.93 \quad a b c$ \\
\hline & & NO & $2.88 \pm 0.24 b c$ & $7.76 \pm 0.50 \mathrm{ab}$ & $30.5 \pm 3.2$ & $b$ & & $4.05 \pm 0.32 b$ & $11.82 \pm 0.74 c$ \\
\hline & Inter- & $N 1$ & $3.38 \pm 0.28 c$ & $8.12 \pm 0.49 b$ & $36.8 \pm 3.2$ & bc & & $4.31 \pm 0.39 b$ & $11.62 \pm 0.74 b c$ \\
\hline & crop & N2 & $4.76 \pm 0.49 \mathrm{~d}$ & $6.85 \pm 0.53 a b$ & $51.7 \pm 3.6$ & d & & $5.86 \pm 0.56 c$ & $9.50 \pm 0.69 a b$ \\
\hline & & N3 & $5.68 \pm 0.56 \mathrm{e}$ & $6.37 \pm 0.32 a$ & $72.7 \pm 5.8$ & e & & $7.34 \pm 0.73 \mathrm{~d}$ & $8.12 \pm 0.43 \quad a$ \\
\hline \multirow[t]{8}{*}{$P: T$} & & $\overline{P O}$ & $1.07 \pm 0.05 a$ & $6.52 \pm 0.23 a$ & $19.7 \pm 1.2$ & $a$ & $\overline{160.4 \pm 6.1 \quad \mathrm{a}}$ & $1.37 \pm 0.09 a$ & $6.04 \pm 0.24 \quad a$ \\
\hline & Sole & $P 1$ & $2.64 \pm 0.22 b$ & $7.67 \pm 0.30 a b c$ & $30.2 \pm 3.1$ & $b$ & $215.9 \pm 14.2 \mathrm{ab}$ & $3.61 \pm 0.30 b$ & $9.38 \pm 0.38 \quad b$ \\
\hline & Crop & $P 2$ & $3.02 \pm 0.24 b$ & $7.86 \pm 0.38 a b c$ & $28.4 \pm 2.9$ & $b$ & $199.2 \pm 13.0 \mathrm{ab}$ & $4.06 \pm 0.31 b$ & $11.14 \pm 0.58 \mathrm{bcd}$ \\
\hline & & P3 & $2.8 \pm 0.24 \quad b$ & $8.38 \pm 0.38 b c$ & $26.6 \pm 2.8$ & $a b$ & $223.1 \pm 15.6 \mathrm{ab}$ & $3.93 \pm 0.30 \mathrm{~b}$ & $13.06 \pm 0.50 \mathrm{~d}$ \\
\hline & & $P O$ & $1.55 \pm 0.10 \mathrm{a}$ & $8.85 \pm 0.30 c$ & $25.8 \pm 1.6$ & $a b$ & $226.4 \pm 14.3 b$ & $1.96 \pm 0.09 a$ & $10.05 \pm 0.42 b c$ \\
\hline & Inter- & $P 1$ & $4.53 \pm 0.30 c$ & $6.90 \pm 0.37 a b$ & $53.4 \pm 5.1$ & c & $190.1 \pm 15.9 \mathrm{ab}$ & $5.82 \pm 0.42 c$ & $9.13 \pm 0.56 b$ \\
\hline & crop & $P 2$ & $5.36 \pm 0.40 \mathrm{~d}$ & $6.41 \pm 0.47 a$ & $56.4 \pm 5.4$ & c & $186.2 \pm 16.3 \mathrm{ab}$ & $6.79 \pm 0.43 \mathrm{~d}$ & $9.86 \pm 0.83 \quad b c$ \\
\hline & & P3 & $5.39 \pm 0.41 \mathrm{~d}$ & $6.84 \pm 0.56 \mathrm{ab}$ & $58.0 \pm 5.5$ & c & $192.4 \pm 21.5 \mathrm{ab}$ & $7.16 \pm 0.45 \mathrm{~d}$ & $11.77 \pm 0.90 \mathrm{~cd}$ \\
\hline
\end{tabular}


Table S2. Means \pm standard errors of RYM_P (relative yield of mixture calculated from phosphorus $(P)$ content by plants) and $R I I$ (relative interaction intensity) of wheat and lupin, in different treatments. Only factors having a significant effect are

793 shown. Within a column, different letters denote significant difference $(P<0.05)$.

\begin{tabular}{|c|c|c|c|c|c|}
\hline & & \multirow{2}{*}{$\begin{array}{c}\text { Relative yield } \\
\text { of mixture } \\
\text { (Phosphorus) }\end{array}$} & \multicolumn{3}{|c|}{ Relative interaction intensity (RII) } \\
\hline & & & Wheat & & Lupin \\
\hline \multirow[t]{4}{*}{$N$} & $\overline{N O}$ & & & & $-0.02 \pm 0.04 \mathrm{al}$ \\
\hline & $N 1$ & & & & $0.03 \pm 0.04 \quad b$ \\
\hline & N2 & & & & $-0.04 \pm 0.04$ a \\
\hline & N3 & & & & $-0.11 \pm 0.04 a$ \\
\hline \multirow[t]{4}{*}{$P$} & PO & $1.39 \pm 0.04 b$ & $0.17 \pm 0.02$ & a & $0.15 \pm 0.02 b$ \\
\hline & P1 & $1.25 \pm 0.04 \mathrm{a}$ & $0.27 \pm 0.02$ & $b$ & $-0.06 \pm 0.03 a$ \\
\hline & $P 2$ & $1.25 \pm 0.05 \mathrm{a}$ & $0.28 \pm 0.02$ & $b$ & $-0.11 \pm 0.04 a$ \\
\hline & P3 & $1.27 \pm 0.04 a$ & $0.32 \pm 0.02$ & $b$ & $-0.12 \pm 0.05 a$ \\
\hline
\end{tabular}

795 


\begin{tabular}{|c|c|c|c|c|c|c|c|c|c|}
\hline & & & \multicolumn{2}{|c|}{ Shoot to root biomass ratio } & \multicolumn{3}{|c|}{$\begin{array}{l}\text { Fraction of belowground dry } \\
\text { biomass (\%) }\end{array}$} & \multirow{2}{*}{\multicolumn{2}{|c|}{$\begin{array}{c}\text { Nitrogen derived } \\
\text { from atmosphere } \\
(\%)\end{array}$}} \\
\hline & & & Wheat & Lupin & Cluster roots & Nodules & & & \\
\hline \multirow[t]{4}{*}{$\bar{N}$} & & NO & $3.24 \pm 0.25 a$ & & & $3.25 \pm 0.12$ & $\bar{c}$ & $85.37 \pm 1.16$ & $\bar{c}$ \\
\hline & & N1 & $3.73 \pm 0.29 a b$ & & & $3.18 \pm 0.12$ & c & $81.76 \pm 1.85$ & c \\
\hline & & N2 & $3.98 \pm 0.24 b$ & & & $2.64 \pm 0.11$ & b & $69.25 \pm 2.39$ & b \\
\hline & & N3 & $4.18 \pm 0.21 b$ & & & $2.12 \pm 0.12$ & $\mathrm{a}$ & $56.94 \pm 3.38$ & $\mathrm{a}$ \\
\hline \multirow[t]{4}{*}{$P$} & & $P O$ & $5.45 \pm 0.29 b$ & & $7.52 \pm 0.71 b$ & $2.37 \pm 0.11$ & $a$ & $66.45 \pm 3.12$ & $\mathrm{a}$ \\
\hline & & P1 & $3.48 \pm 0.17 a$ & & $4.87 \pm 0.36 a$ & $2.69 \pm 0.15$ & $a b$ & $72.76 \pm 3.07$ & $\mathrm{~b}$ \\
\hline & & $P 2$ & $3.08 \pm 0.14 a$ & & $5.06 \pm 0.48 a$ & $3.03 \pm 0.13$ & $b$ & $76.70 \pm 2.95$ & $\mathrm{~b}$ \\
\hline & & P3 & $3.10 \pm 0.15 a$ & & $4.36 \pm 0.33 a$ & $3.04 \pm 0.14$ & $b$ & $75.70 \pm 2.61$ & $\mathrm{~b}$ \\
\hline \multirow{2}{*}{$\mathrm{T}$} & Sole C & rop & $4.25 \pm 0.19 b$ & $3.34 \pm 0.09 a$ & $5.98 \pm 0.39 b$ & $2.61 \pm 0.10$ & $a$ & $63.99 \pm 2.12$ & $\mathrm{a}$ \\
\hline & Interci & rop & $3.33 \pm 0.16 a$ & $3.96 \pm 0.09 b$ & $4.95 \pm 0.36 a$ & $2.97 \pm 0.09$ & $\mathrm{~b}$ & $81.83 \pm 1.55$ & $\mathrm{~b}$ \\
\hline \multirow[t]{16}{*}{$N: P$} & & $P O$ & & & & & & $84.33 \pm 1.60$ & gh \\
\hline & $N \cap$ & $P 1$ & & & & & & $89.16 \pm 2.00$ & \\
\hline & NO & $P 2$ & & & & & & $86.79 \pm 2.27$ & $\mathrm{~h}$ \\
\hline & & P3 & & & & & & $82.72 \pm 2.76$ & fgh \\
\hline & & $P O$ & & & & & & $78.86 \pm 2.34$ & defgh \\
\hline & $N 1$ & P1 & & & & & & $83.22 \pm 3.07$ & fgh \\
\hline & $N \perp$ & $P 2$ & & & & & & $85.25 \pm 2.37$ & gh \\
\hline & & P3 & & & & & & $80.01 \pm 5.80$ & efgh \\
\hline & & PO & & & & & & $63.73 \pm 2.93$ & $\mathrm{bc}$ \\
\hline & 2 & P1 & & & & & & $69.11 \pm 4.48$ & bcdef \\
\hline & INZ & $P 2$ & & & & & & $70.61 \pm 6.85$ & bcdefg \\
\hline & & P3 & & & & & & $73.55 \pm 4.23$ & cdefgh \\
\hline & & PO & & & & & & $38.89 \pm 3.85$ & $\mathrm{a}$ \\
\hline & $N 13$ & $P 1$ & & & & & & $58.20 \pm 6.12$ & $\mathrm{~b}$ \\
\hline & NS & $P 2$ & & & & & & $64.14 \pm 7.21$ & bcd \\
\hline & & P3 & & & & & & $66.52 \pm 6.47$ & bcde \\
\hline \multirow[t]{8}{*}{$N: T$} & & NO & & & & $3.17 \pm 0.15$ & $\mathrm{~cd}$ & $83.33 \pm 1.03$ & de \\
\hline & Sole & $N 1$ & & & & $3.20 \pm 0.19$ & $d$ & $74.08 \pm 2.56$ & $\mathrm{~cd}$ \\
\hline & Crop & N2 & & & & $2.39 \pm 0.13$ & b & $58.20 \pm 2.51$ & b \\
\hline & & N3 & & & & $1.73 \pm 0.14$ & a & $43.67 \pm 3.40$ & $a$ \\
\hline & & NO & & & & $3.33 \pm 0.19$ & $d$ & $88.41 \pm 1.84$ & $\mathrm{e}$ \\
\hline & Inter- & $N 1$ & & & & $3.16 \pm 0.16$ & $d$ & $89.44 \pm 0.98$ & $\mathrm{e}$ \\
\hline & crop & N2 & & & & $2.90 \pm 0.17$ & bcd & $80.30 \pm 2.08$ & de \\
\hline & & N3 & & & & $2.52 \pm 0.15$ & bc & $70.21 \pm 4.11$ & c \\
\hline \multirow[t]{8}{*}{$P: T$} & & $P O$ & & & & & & $60.96 \pm 4.42$ & $\mathrm{a}$ \\
\hline & Sole & $P 1$ & & & & & & $63.70 \pm 4.48$ & $a b$ \\
\hline & Crop & $P 2$ & & & & & & $64.66 \pm 4.35$ & $a b$ \\
\hline & & P3 & & & & & & $66.58 \pm 3.94$ & $a b$ \\
\hline & & $P O$ & & & & & & $71.94 \pm 4.17$ & $b$ \\
\hline & Inter- & $P 1$ & & & & & & $81.82 \pm 2.93$ & c \\
\hline & crop & $P 2$ & & & & & & $88.73 \pm 1.25$ & c \\
\hline & & P3 & & & & & & $84.83 \pm 1.94$ & c \\
\hline
\end{tabular}




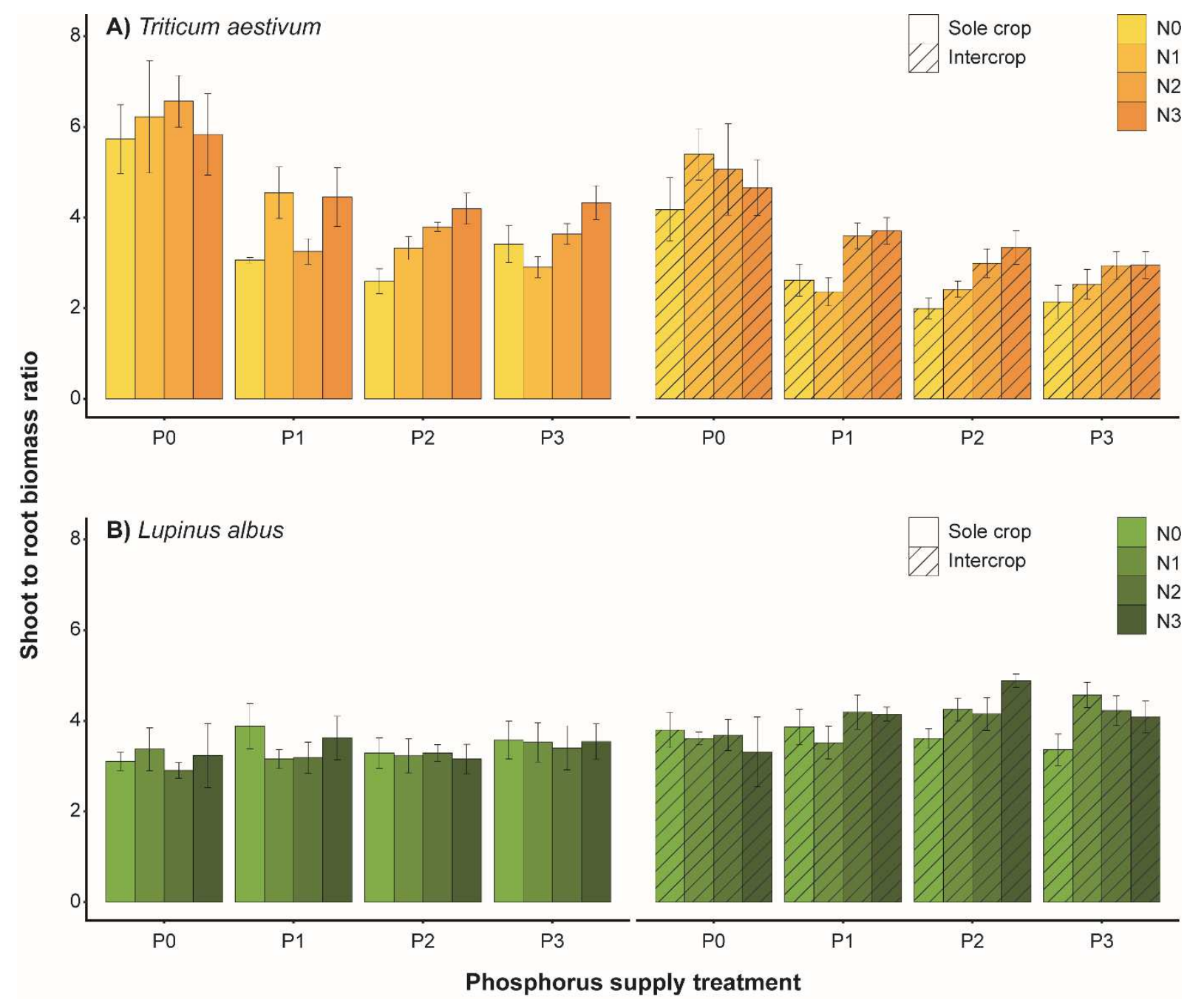

802 Figure S1. Shoot to root ratio of wheat $(A)$ and lupin $(B)$ at the end of the experiment. Vertical bars represent standard error. 803 NO, N1, N2, N3 stand for the four levels of N, and PO, P1, P2, P3 stand for the four levels of $P$. 